\title{
60 YEARS OF NEUROENDOCRINOLOGY Redefining neuroendocrinology: stress, sex and cognitive and emotional regulation
}

\section{Bruce S McEwen, Jason D Gray and Carla Nasca}

Laboratory of Neuroendocrinology, The Rockefeller University, 1230 York Avenue, New York, New York 10065, USA
Correspondence should be addressed

to B S McEwen

Email

mcewen@rockefeller.edu

\begin{abstract}
The discovery of steroid hormone receptors in brain regions that mediate every aspect of brain function has broadened the definition of 'neuroendocrinology' to include the reciprocal communication between the brain and the body via hormonal and neural pathways. The brain is the central organ of stress and adaptation to stress because it perceives and determines what is threatening, as well as the behavioral and physiological responses to the stressor. The adult and developing brain possess remarkable structural and functional plasticity in response to stress, including neuronal replacement, dendritic remodeling, and synapse turnover. Stress causes an imbalance of neural circuitry subserving cognition, decision-making, anxiety and mood that can alter expression of those behaviors and behavioral states. This imbalance, in turn, affects systemic physiology via neuroendocrine, autonomic, immune and metabolic mediators. In the short term, as for increased fearful vigilance and anxiety in a threatening environment, these changes may be adaptive. But, if the danger passes and the behavioral state persists along with the changes in neural circuitry, such maladaptation may need intervention with a combination of pharmacological and behavioral therapies, as is the case for chronic anxiety and depression. There are important sex differences in the brain responses to stressors that are in urgent need of further exploration. Moreover, adverse early-life experience, interacting with alleles of certain genes, produce lasting effects on brain and body over the life-course via epigenetic mechanisms. While prevention is most important, the plasticity of the brain gives hope for therapies that take into consideration brain-body interactions.
\end{abstract}
Key Words
- neuroendocrinology
- hormone action
- behaviour
- brain
- stress hormones

Journal of Endocrinology (2015) 226, T67-T83

\section{Introduction}

The fundamental discovery of the communication between hypothalamus and pituitary, by Geoffrey Harris, established the basis for understanding brain-body communication via the neuroendocrine system (Harris 1970).
As originally conceived and confirmed by the releasing factors in the hypothalamus for pituitary hormones (Schally et al. 1973, Guillemin 1978, Vale et al. 1981), the field of neuroendocrinology has flourished. At the

This paper is part of a thematic review section on 60 years of neuroendocrinology. The Guest Editors for this section were Ashley Grossman and Clive Coen. 
same time, steroid hormones were shown to bind to intracellular receptors that regulate gene expression in tissues such as liver, or the prostate and uterus in the case of sex hormones (Jensen \& Jacobson 1962). The focus of steroid hormone feedback to regulate neuroendocrine function was naturally upon the pituitary and the hypothalamus and this important work continues to uncover essential aspects of neuroendocrine regulation (Meites 1992).

The McEwen laboratory entered this field by serendipitously discovering adrenal steroid, and later estrogen receptors, in the hippocampal formation of the rat (McEwen et al. 1968, McEwen \& Plapinger 1970, Gerlach \& McEwen 1972, Loy et al. 1988, Milner et al. 2001) and we, and others, extended these findings to the infrahuman primate brain, as well as to other regions of the brain involved in cognitive and emotional regulation (Gerlach et al. 1976). This has catalyzed studies that look at actions of hormonal feedback on the brain not only to regulate hypothalamic functions but also to influence neurological, cognitive and emotional functions of the whole brain, with translation to the human brain in relation to aging, mood disorders and the impact of the social environment. This article describes research in our, and other laboratories, that redefined neuroendocrinology as a field that also studies two-way brain body communication via the neuroendocrine, autonomic, immune and metabolic systems. This research has uncovered the remodeling of brain architecture mediated by hormones working together with other cellular mediators. These actions occur via epigenetic mechanisms involving both genomic and non-genomic processes over the life course, and there is ongoing translation of the findings in animal models to the human condition, including the effects of adverse early-life experiences and the relationship of socioeconomic status and health through the development of the concept of allostatic load.

\section{Receptors outside of the hypothalamus}

By administering ${ }^{3} \mathrm{H}$ corticosterone into adrenalectomized rats, we discovered receptors for adrenal steroids in the hippocampal formation of the rat and, later, the rhesus monkey (McEwen et al. 1968, McEwen \& Plapinger 1970, Gerlach \& McEwen 1972, Gerlach et al. 1976; Fig. 1). Other work revealed such receptors in the hippocampal equivalent in other species, including birds (McEwen 1976, Dickens et al. 2009). In retrospect, these findings broadened the perspective that glucocorticoids provided negative feedback control of the HPA axis to include actions of adrenal steroids on other brain functions such as memory, learning, control of mood, and other aspects of behavior (McEwen 2010).

Work by Reul and de Kloet demonstrated that there are two types of adrenal steroid receptors, mineralocorticoid (type 1 or MR) and glucocorticoid (type 2 or GR), in hippocampus and other brain regions (Reul \& DeKloet 1985). This was further elaborated by immunocytochemical mapping of the receptors (Ahima \& Harlan 1990, Ahima et al. 1991). Studies in our laboratory, as well as by Diamond

Memory of daily events, spatial memory Mood regulation - target of depression

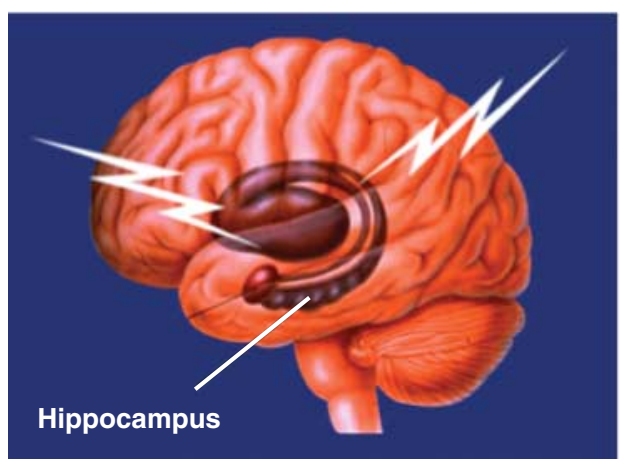

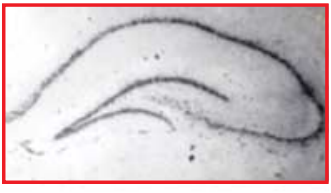

Adrenal steroid receptors in hippocampus

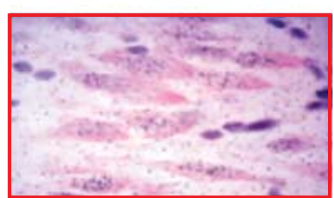

Receptors in cell nuclei regulate gene expression 'MR' and 'GR'

\section{Figure 1}

The hippocampal formation is a target of adrenocortical steroids and is involved in spatial and episodic memory, as well as mood regulation. Both pyramidal neurons in Ammon's horn and neurons of the dentate express type I or mineralocorticoid (MR) and type 2 or glucocorticoid (GR) receptors. 
and Joëls, have shown biphasic effects mediated by MR and GR (Diamond et al. 1992, Pavlides et al. 1995, Joels 2006). Ultradian fluctuations of glucocorticoids drive GR activation and reactivation, while MR occupancy for nuclear activation is more constant and promotes excitability (Stavreva et al. 2009). Moreover, membrane associated GR and MR are linked to the direct stimulation of excitatory amino acid release (Karst et al. 2005, Popoli et al. 2012).

Much of this information was obtained via studies on the hippocampus, which has become a gateway into the study of hormone effects on other brain regions involved in cognitive and emotional regulation and other behaviors. The hippocampus is important for episodic and spatial memory and is now also recognized for its role in mood regulation, as will be explained in the following section. For spatial memory (Fig. 2), the hippocampus becomes active in London cab drivers during functional MRI imaging when they remember a route from one place to another (Maguire et al. 1997) and the hippocampus is also important for food caching behavior in squirrels and birds (Biegler et al. 2001, Clayton 2001, Burger et al. 2013).
The hippocampus is also 'the canary in the coal mine' as far as conditions such as ischemia and seizures that cause brain damage as well as brain aging (Sapolsky 1990). And the hippocampus responds to sex hormones with effects on spatial memory and other functions (Sandstrom \& Williams 2001), as discussed later in this review.

\section{Output to multiple interacting mediators and the concept of allostatic load}

As originally defined, neuroendocrinology refers to the hypothalamic and pituitary control of neuroendocrine function. The McEwen laboratory has focused upon the return loop of feedback of steroid hormones on the brain to affect molecular, cellular, physiological and behavioral processes throughout the entire brain. This feedback now includes action in the brain of metabolic hormones such as insulin, ghrelin, insulin-like growth factor 1 (IGF1) and leptin via specific uptake systems and acting upon receptors residing in hippocampus and other brain regions (McEwen 2007; Fig. 3). Moreover, given the influence of

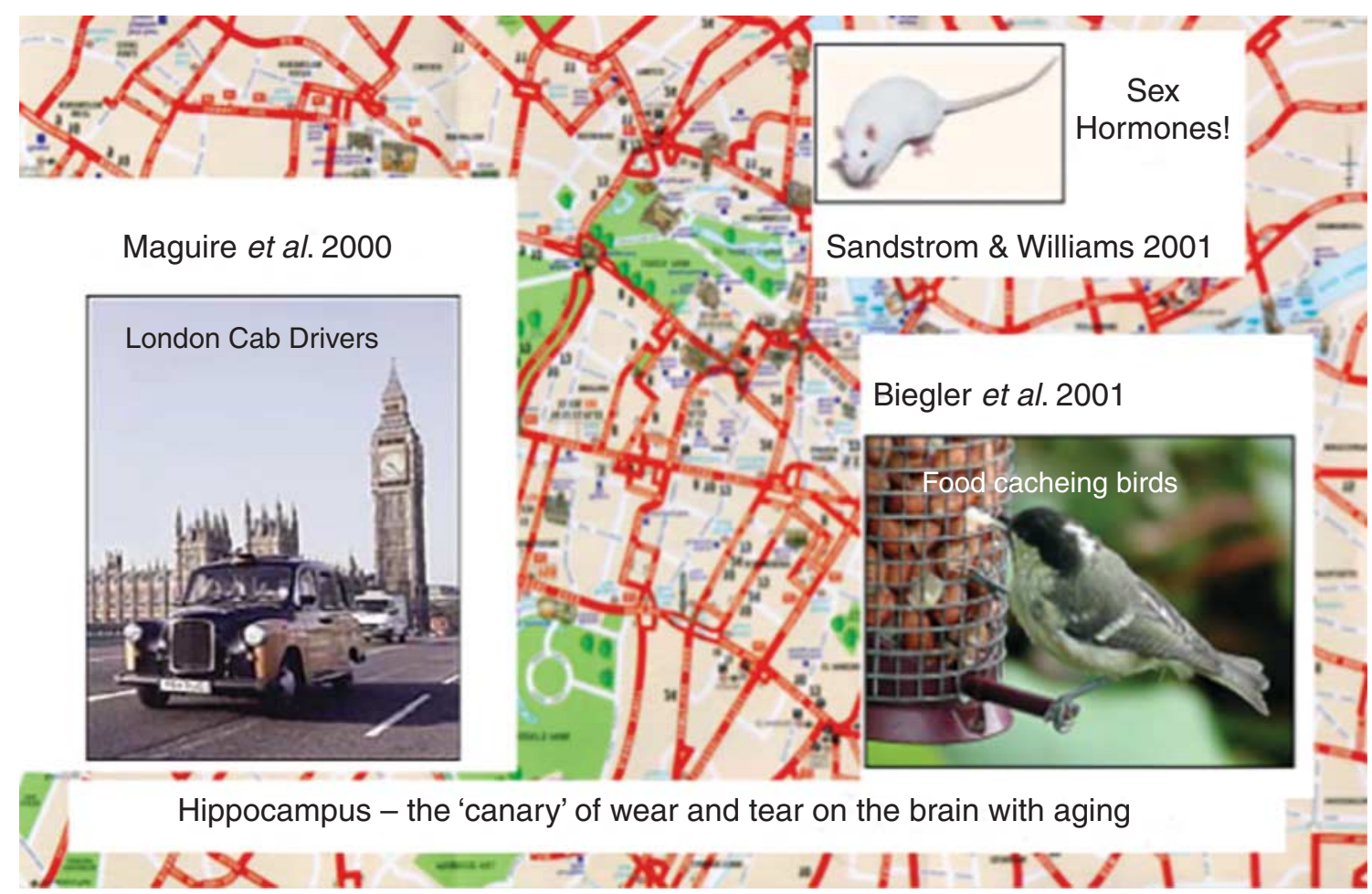

\section{Figure 2}

The hippocampal formation is activated in spatial memory as in the London Cab Driver's study (Maguire et al. 1997), as well as in spatial location of food in food-caching birds and squirrels. The hippocampus is also a target of sex hormones that affect spatial memory (Sandstrom \& Williams 2004).
(C) 2015 Society for Endocrinology Printed in Great Britain
The hippocampus is also sensitive to damage by seizures, ischemia and head trauma in which glucocorticoids synergize effects of excitatory amino acid overload (Sapolsky 1990).

Published by Bioscientifica Ltd 


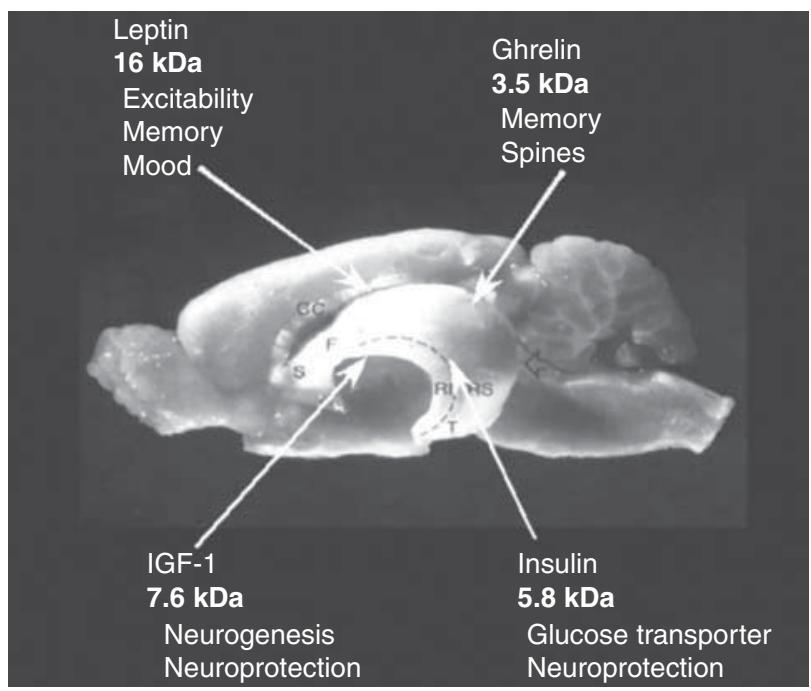

Figure 3

Four peptide/protein hormones, insulin-like growth factor 1 (IGF1), insulin, ghrelin, and leptin, are able to enter the brain and affect structural remodeling or other functions in the hippocampus. A transport process is involved, and specific receptors are expressed in hippocampus, as well as in other brain regions. Molecular sizes are indicated for each hormone in $\mathrm{kDa}$ : ghrelin, $3.5 \mathrm{kDa}$; leptin, $16 \mathrm{kDa}$; insulin, $5.8 \mathrm{kDa}$; IGF1, 7.6 kDa. Reproduced, with permission, from McEwen BS (2007) Physiology and neurobiology of stress and adaptation: central role of the brain. Physiological Reviews 87 873-904. Copyright 2007 the American Physiological Society.

hormones and autonomic outflow from the brain upon activity of the immune system, the direct and indirect feedback actions of circulating cytokines on the brain must also be considered in a broader definition of neuroendocrinology (Maier \& Watkins 1998). Furthermore, the autonomic nervous system itself, both parasympathetic and sympathetic arms, is a partner of neuroendocrine regulation as is here more broadly defined (Sloan et al. 1999, Tracey 2002).

Within this broader view of neuroendocrinology in relation to brain-body communication, we modified the concept of allostasis (Sterling \& Eyer 1988) to refer to the active process of maintaining homeostasis via output of hormones and autonomic nervous system (ANS) activity, and we developed the concept of allostatic load and overload as a means of better understanding the cumulative and potentially damaging, as well as protective, effects of stressors on the brain and body (McEwen \& Stellar 1993, McEwen 1998, McEwen \& Wingfield 2003, McEwen \& Gianaros 2011). Because the mediators of allostasis interact and affect each other's activity and because each mediator system has biphasic effects in dose and time, the 'network of allostasis' is nonlinear (McEwen 2006). When one mediator system changes, the others adjust, and the resulting output can be distorted, as in chronic inflammation or a flat cortisol diurnal rhythm caused by sleep deprivation or depression.

Another important feature of the allostatic load concept is the notion that the mediators that normally help the body and brain adapt to stressors can also become distorted and contribute to cumulative, pathophysiological change such as atherosclerosis or obesity and diabetes (McEwen 1998). Finally, and importantly, the allostatic load concept emphasizes the central role of the brain in response to adaptation to stressors because of its central role in regulating and responding to the broaderdefined 'neuroendocrine' system (McEwen 1998; Fig. 4). Both the physical and social environment contribute to experiences that require adaptation of brain architecture and physiological processes (McEwen \& Gianaros 2011), as is discussed later in this review. Quite recently, the epigenetic allostasis concept has introduced another feature of the allostatic load to emphasize the influence of early-life experiences on the development of mood disorders in susceptible individuals and this also points to the key role of MR receptors in the communication with the glutamate system (Nasca et al. 2014), as discussed in the next section.

\section{Structural plasticity of brain regions mediating cognition and affect}

A remarkable feature of the adult, as well as the developing brain, is its capacity for remodeling of dendrites, turnover of synapses and neurogenesis. We discovered that remodeling of dendrites in the hippocampus in response to chronic stress caused shrinking of dendrites in the CA3 subfield that was also mimicked by chronic glucocorticoid treatment, but also involved mediation by excitatory amino acids and other cellular mediators (McEwen 1999; Fig. 5). Similar shrinkage of dendrites was found in medial prefrontal cortex after chronic stress, whereas expansion of dendrites in basolateral amygdala was found under the same conditions (Vyas et al. 2002, Radley et al. 2004). In hippocampus of hibernating animals, rapid shrinkage of CA3 apical dendrites is seen with onset of hibernation while regrowth of those dendrites occurs within hours of termination of hibernation, suggesting that the cytoskeleton can rapidly depolymerize and repolymerize when needed via a mechanism in which tau phosphorylation is involved (Arendt et al. 2003, Magarinos et al. 2006).

The turnover of spine synapses also occurs in response to stressors and this was shown quite recently in the case of the HPA axis to be dependent on the ultradian pulses of glucocorticoids (Liston \& Gan 2011, Liston et al. 2013).

Published by Bioscientifica Ltd 


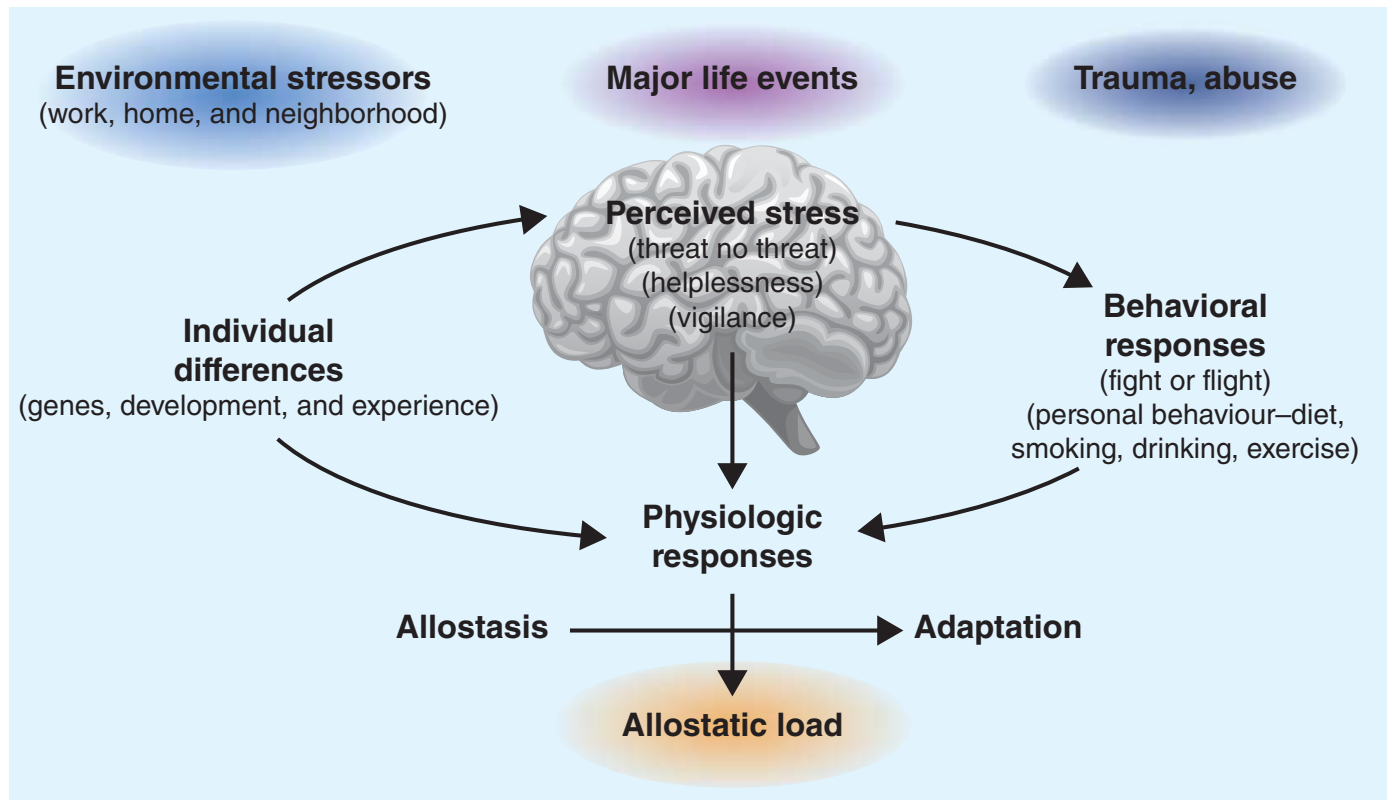

\section{Figure 4}

The stress response and development of allostatic load. The perception of stress is influenced by one's experiences, genetics, and behavior. When the brain perceives an experience as stressful, physiologic and behavioral responses are initiated, leading to allostasis and adaptation. Over time, allostatic load can accumulate, and the overexposure to mediators of

Chronic stress causes reduced spine density in hippocampus and medial prefrontal cortex, as well as medial amygdala, and increased spine density occurs in basolateral amydala (McEwen \& Chattarji 2007). Sex hormones also regulate spine synapse turnover in hippocampus, hypothalamus, and prefrontal cortex of female rats and rhesus monkeys by a mechanism involving not only estradiol $\left(\mathrm{E}_{2}\right)$, but also excitatory amino acids and NMDA receptors (Frankfurt et al. 1990, McEwen et al. 1995, Woolley 1999, Dumitriu et al. 2010; Fig. 6).

Structural plasticity also occurs among interneurons involving spine turnover and dendritic remodeling, as well as neurogenesis (Cameron \& Dayer 2008, Nacher et al. 2013). As first suggested by Altman (1962), there is turnover and neurogenesis of inhibitory interneurons in the adult cortex occurring at about the same rate as that of granule neurons in the dentate gyrus (Cameron \& Dayer 2008). Spine synapse turnover and dendritic remodeling is evident in a class of interneurons that express polysialated neural cell adhesion molecule (PSA-NCAM) and which are widely distributed in the telencephalon of rodents and humans (Nacher et al. 2013). Dopamine acting via D2 receptors affects PSA-NCAM expression and some dopamine effects are blocked by the depletion of PSA (Nacher et al. 2013). neural, endocrine, and immune stress can have adverse effects on various organ systems, leading to disease. Reproduced, with permission, from McEwen BS (1998) Protective and damaging effects of stress mediators. New England Journal of Medicine 338 171-179. Copyright 1998 Massachusetts Medical Society.

Neurogenesis in the dentate gyrus of the adult hippocampus was rediscovered by Elizabeth Gould and Heather Cameron based upon earlier work by Altman and Kaplan and findings in the songbird brain by Nottebohm and colleagues (Cameron \& Gould 1994, Kaplan 2001, Alvarez-Buylla \& Garcia-Verdugo 2002, Nottebohm 2002, Gould 2007). Glucocorticoids and excitatory amino acids are both involved in stress-induced suppression of neurogenesis, which was found not only in rodents, but also in tree shrews and rhesus monkeys (Cameron \& Gould 1994, Gould et al. 1997, 1998). Yet, glucocorticoid levels do not predict the direction of neurogenesis, as shown by studies of male sexual behavior in which increased neurogenesis is found with high glucocorticoid levels; oxytocin appears to play an important role in glucocorticoid mediated neurogenesis (Leuner et al. 2010, 2012).

Repeated stress in rats has been shown to lead to reduced cell proliferation and neuron number in the dentate gyrus along with reduced dentate gyrus volume (Pham et al. 2003). Conversely, physical activity increases neurogenesis and dentate gyrus volume (van Praag et al. 1999), as also does living in an enriched environment (Kempermann et al. 1997). Hippocampal volume increases in elderly 'couch potatoes' who engage in regular, moderate exercise, such as walking (Erickson et al. 2011).

Published by Bioscientifica Ltd 


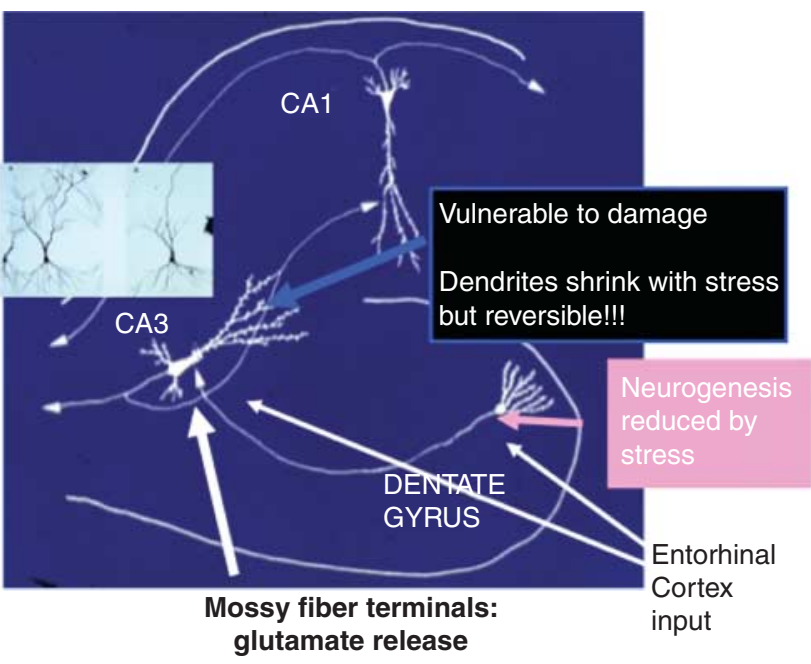

Figure 5

The trisynaptic organization of the hippocampus showing input from the entorhinal cortex to both CA3 and dentate gyrus (DG), with feed forward and feedback connections between these two regions that promote memory formation in space and time but, at the same time, makes the CA3 vulnerable to seizure-induced excitatory (McEwen 1999). Chronic stress causes apical dendrites of CA3 neurons to debranch and shorten in a reversible manner, and glutamate release by giant mossy fiber terminals is a driving force. Chronic stress also inhibits neurogenesis in DG and can eventually reduce DG neuron number and DG volume.

\section{Mechanisms of action of glucocorticoids and estrogens}

As is now recognized for all steroid hormones, glucocorticoids produce effects on their target cells via both direct and indirect genomic effects, as well as non-genomic actions (Fig. 7). Direct actions involve binding of the dimerized GR to the glucocorticoid response element, whereas indirect genomic actions involve tethering of the GR to other transcription factors such as AP1, NfkB or Stat5 (Yamamoto 1985, Ratman et al. 2013). There are also actions of GR on the mitochondrial genome (Du et al. 2009a). Non-genomic actions include the stimulation of endocannabinoid production and direct stimulation of glutamate release, as summarized next.

The role of glucocorticoids and estrogens in structural remodeling of the adult brain also involves multiple interacting mediators (McEwen 2010). In the case of stress and adrenal steroids, tissue plasminogen activator is involved as a mediator of stress induced changes in medial amygdala and CA1 hippocampal spine density, along with corticotrophin releasing hormone (CRH), which is able to stimulate its release (Pawlak et al. 2003, 2005, Chen et al. 2006a). Reduced BDNF expression in haploinsufficiency and in the val66met polymorphism is linked to reduced dendritic growth in hippocampus and lack of response to chronic stress (Chen et al. 2006b, Magarinos et al. 2011), whereas BDNF over-expression is associated with longer dendrites in both hippocampus and amygdala and failure to respond to chronic stress with retraction in hippocampus and elongation in basolateral amygdala (Govindarajan et al. 2006). Lipocalin-2 is induced by acute stress and modulates actin dynamics and it down-regulates mushroom spines in hippocampus after $3 \mathrm{~d}$ restraint stress, while deletion of Lipocalin-2 increases the proportion of mushroom spines along with increased neuronal excitability and anxiety (Mucha et al. 2011). In amygdala, $3 \mathrm{~d}$ restraint stress up-regulates spine density and this effect is lost in lipocalin-2-ko mice (Skrzypiec et al. 2013).

Endocannabinoids generated postsynaptically via acute glucocorticoid stimulation inhibit either glutamate or GABA release presynaptically (Hill \& McEwen 2010) and this affects not only prefrontal and amygdala control of HPA activity, but also effects of stress on medial prefrontal cortex (mPFC) and basolateral amygdala dendritic branching. Deletion of CB1 receptors exacerbates stress-induced retraction of MPFC dendrites (Hill et al. 2011a), whereas deletion of a degradative enzyme, fatty acid amide hydrolase, prevents stress induced dendrite expansion in basolateral amygala neurons (Hill et al. 2013). Endocannabinoids also play a role in shut-off of HPA function, as well as basal CORT (cortisol, human; corticosterone, rodent) levels after chronic stress and habituation of the CORT response to chronic stress and they appear to do so via the prefrontal cortex and amygdala (Hill et al. 2011b).

With regard to estrogen actions, there are multiple targets of genomic and non-genomic actions of $E_{2}$. $\mathrm{E}_{2}$ stimulates both acetylcholine (Towart et al. 2003) and neuropeptide $Y$ release (Ledoux et al. 2009) via presynaptic estrogen receptors and it induces actin polymerization and filopodial formation and translation of PSD95 mRNA via PI3kinase (Fig. 8; Dumitriu et al. 2010). $\mathrm{E}_{2}$ stimulated acetylcholine release that inhibit inhibitory interneurons is believed to be responsible for up-regulation of NMDA receptors that are required for estrogen-induced synapse formation (Weiland 1992, Daniel \& Dohanich 2001, Rudick et al. 2003).

For both $\mathrm{E}_{2}$ and glucocorticoids, mitochondria are targets that affect $\mathrm{Ca}^{++}$sequestration and regulate free radical formation (Brinton 2008, Du et al. 2009b). Both ER $\beta$ and glucocorticoid receptors translocate to mitochondria where they affect metabolic activity that, at physiological levels, promotes $\mathrm{Ca}^{++}$sequestration and regulates free radical formation (Moutsatsou et al. 2001, Rettberg et al. 2014). At high levels of glucocorticoids, the

Published by Bioscientifica Ltd 


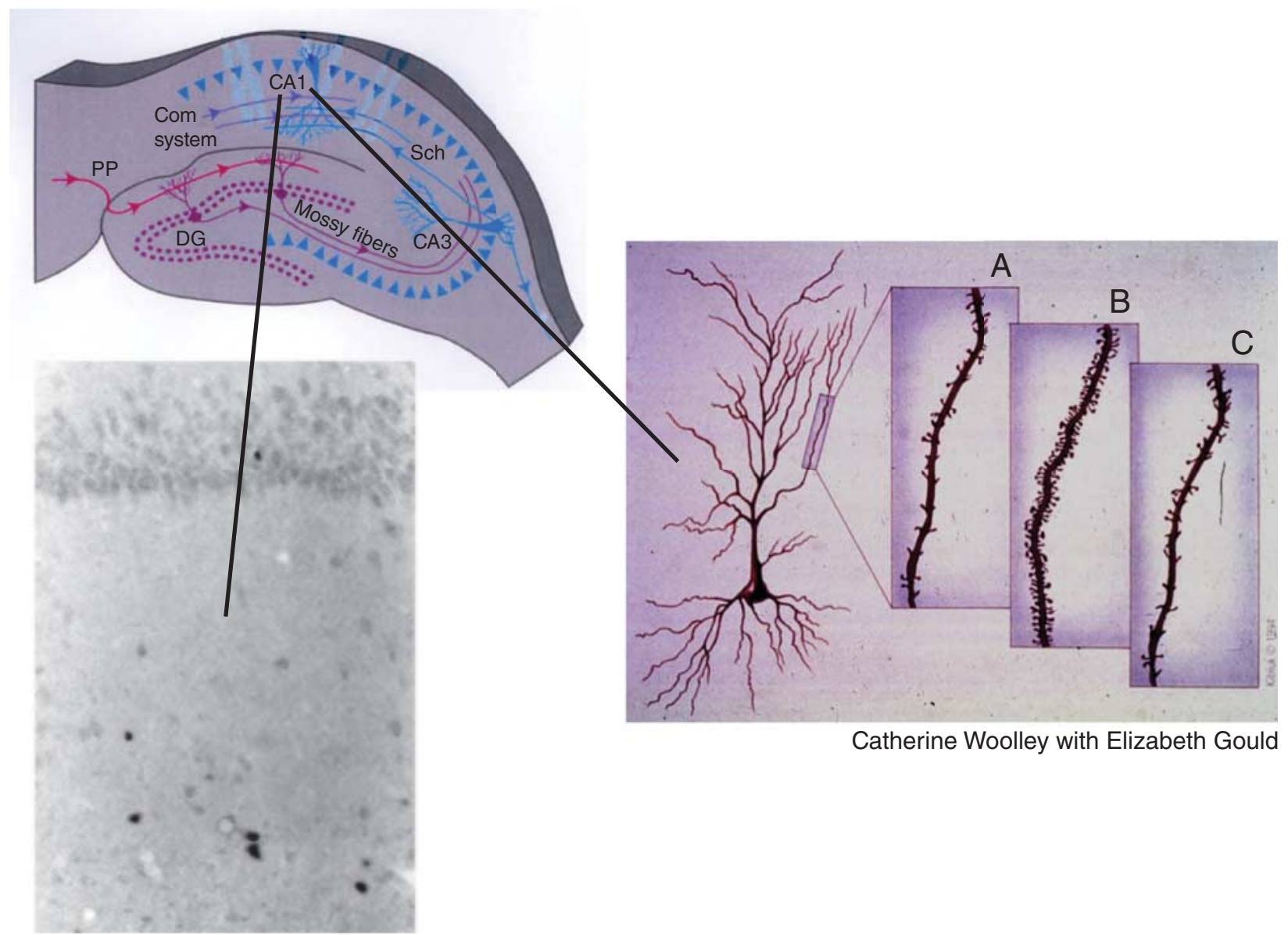

Figure 6

Cyclic ovarian function regulates spine synapse turnover in the CA1 regions of the rat hippocampus and it does so via a combination of nuclear and non-nuclear estrogen receptors. The cell nuclear estrogen receptors are found in a subset of inhibitory interneurons whereas the non-nuclear

sequestration mechanism fail and free radicals and oxidative damage takes place (Du et al. 2009a).

\section{Sex differences}

There are important sex differences in the effects of stress and sex hormones on the hippocampus and prefrontal cortex, extending the seminal work of Harris \& Levine (1965). Chronic stressors in females do not cause dendrites to shrink in CA3 neurons or in medial prefrontal cortex neurons (Galea et al. 1997). In medial prefrontal cortex, neurons that project cortically shrink with chronic stress in males but not in females, whereas neurons that project to the amygdala extend dendrites in females, but not in males, with chronic stress (Shansky et al. 2009, 2010). For the females to respond in this way, there must be circulating estrogens (Shansky et al. 2009). receptors are expressed in presynaptic cholinergic and NPY terminals, in dendrites and mitochondria (McEwen \& Milner 2007, Nilsen et al. 2007, Ledoux et al. 2009).

That such sex differences exist in a brain region like prefrontal cortex not previously thought to be responsive to sex hormones means that there may be sex difference throughout the brain. Indeed, membrane associated estrogen receptors have been found widely throughout the brain (McEwen \& Milner 2007). Studies in men and women of the functional imaging responses of human brain to tests of emotional recognition in which men and women score the same, nevertheless, reveal different patterns of activation across brain regions between the sexes (Derntl et al. 2010).

Reversal of sex differences by manipulations during the critical period for sexual differentiation have shown that males treated with an aromatase inhibitor at birth are able to respond to estrogens to induce synapses in the hippocampus, whereas normally males do not respond to $\mathrm{E}_{2}$, but do respond to testosterone and dihydrotestosterone

Published by Bioscientifica Ltd 


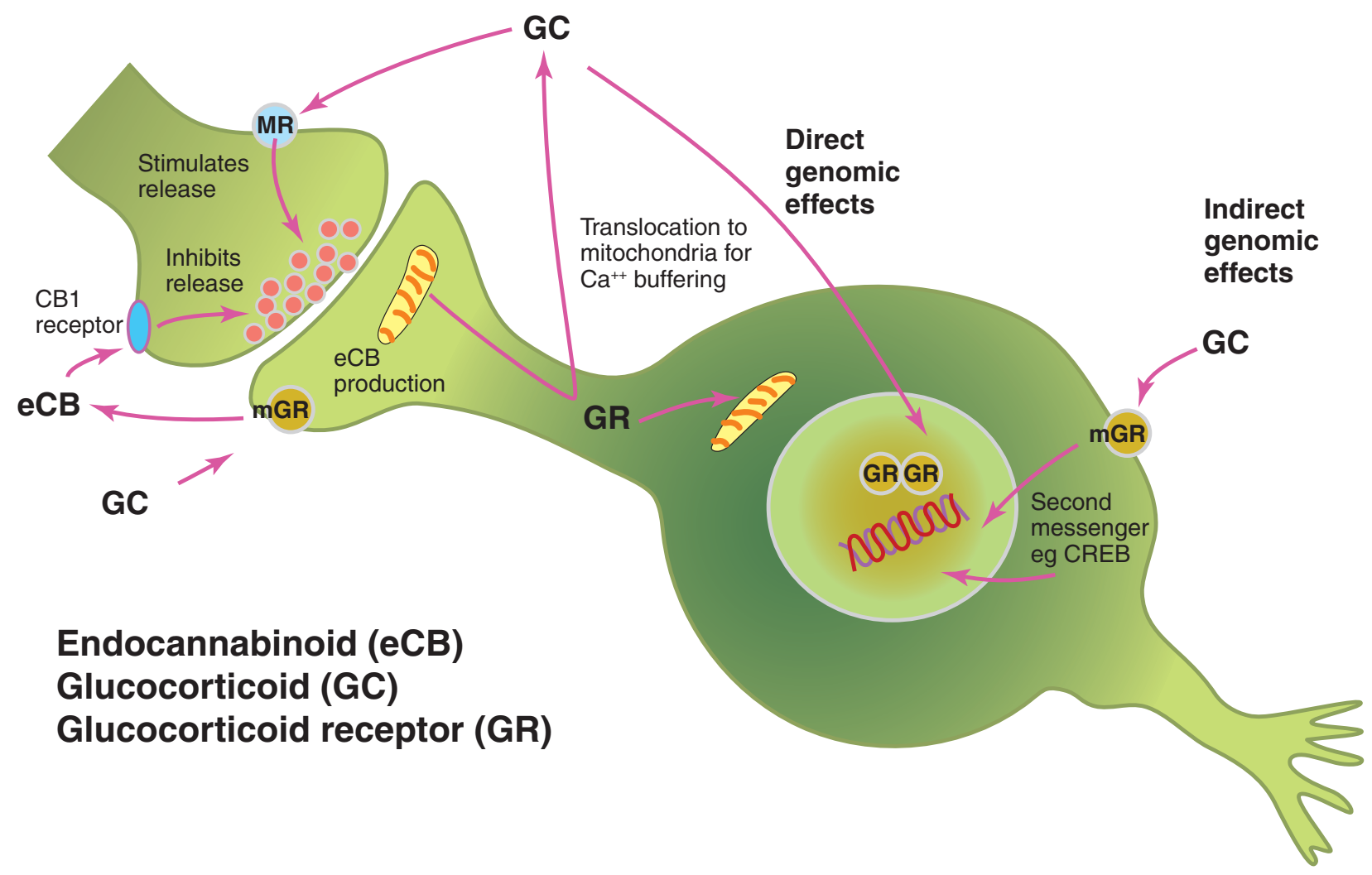

Figure 7

Glucocorticoids produce both direct and indirect genomic effects, and actions via translocation into mitochondria, as well as direct stimulation of presynaptic glutamate release and other non-genomic actions via signaling pathways that activate endocannabinoid synthesis.

for spine synapse induction (Lewis et al. 1995, Leranth et al. 2003). This is the converse of testosterone treatment of newborn females which defeminizes the ability of ovulation and respond with lordosis (Goy \& McEwen 1980). It is important to note that aromatization of testosterone plays a key role in the defeminizing aspects of sexual differentiation postnatally, whereas conversion of testosterone to dihydrotestosterone is involved in masculinizing aspects of brain sexual differentiation that generally occur before birth in the rodent (Naftolin et al. 1971, McEwen et al. 1977, Naftolin 1994).

Spine synapse induction, that is produced by $\mathrm{E}_{2}$ in adult female hippocampus and by dihydrotestosterone in male hippocampus, involves somewhat different mechanisms. In the female, as previously described, there are multiple mechanisms involving both genomic and non-genomic actions of $\mathrm{E}_{2}$ and both cholinergic and GABAergic, as well as NMDA receptor mediated activity and $\mathrm{E}_{2}$ stimulated signaling via PI3kinase (McEwen et al. 2001). In the male, where there are genomic androgen receptors in the CA1 region, as well as non-genomic receptors, the cholinergic system does not appear to be involved while androgens upregulate NMDA receptors; this is a topic that needs more in-depth investigation (Romeo et al. 2005).

\section{Gene expression in an ever-changing brain}

We have found that the expression of genes in the brain is changing continuously with experiences and that novel stressors have different effects upon gene expression in a naïve brain, a chronically stressed brain and a brain recovered from chronic stress. High throughput gene expression profiling of the hippocampal response to an acute forced swim stress revealed a distinct pattern of gene regulation between stress-naïve mice and mice subjected to a forced swim after exposure to 3 weeks of chronic restraint stress (Gray et al. 2014). Further, mice allowed 3 weeks of recovery from chronic stress, which exhibited a normalization of anxiety-like behaviors, still revealed a gene expression profile that was different from the stress naïve state and produced a still different gene expression profile in response to a novel stress. An acute CORT challenge given to either stress naïve or chronically stressed rats also revealed highly different gene expression profiles,

Published by Bioscientifica Ltd 


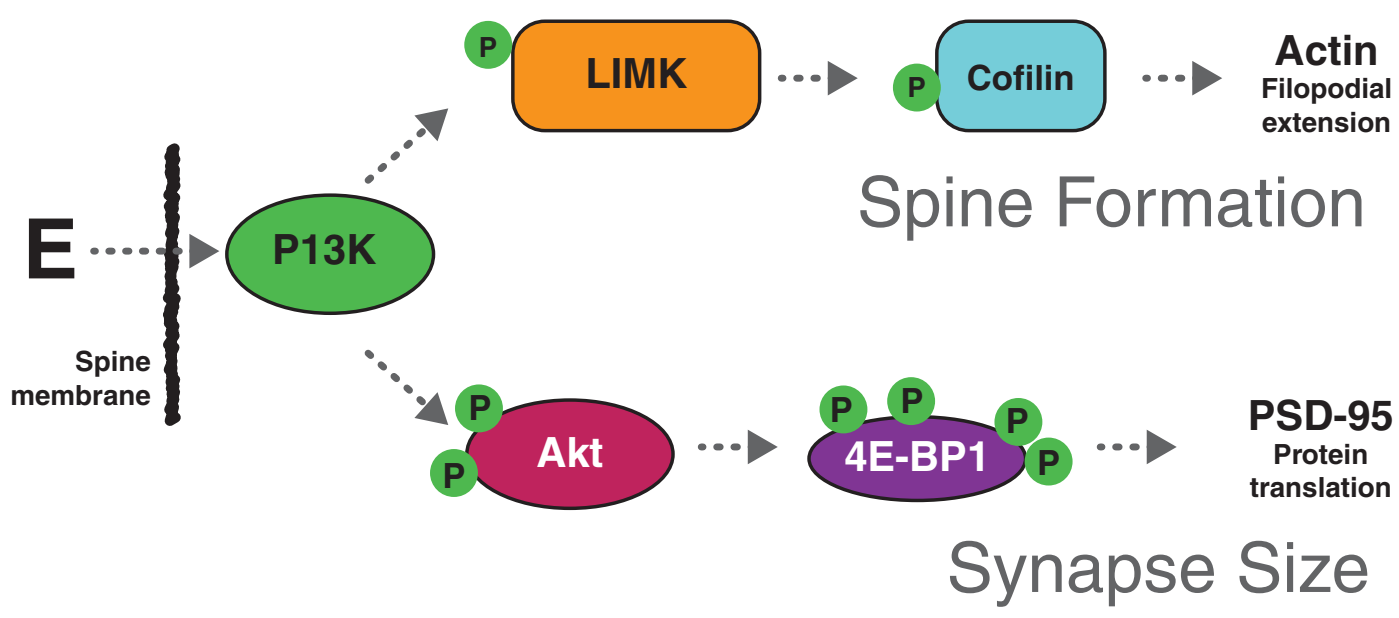

\section{Figure 8}

Non-genomic effects of estrogen. Estrogen initiates a complex set of signal transduction pathways in the hippocampal neuron via several membranebound receptors. Above are two examples of estrogen-initiated signal transduction leading to spinogenesis and changes in synapse size. Rapid activation of Akt (protein kinase B) via PI3K is thought to be mediated by ER $\alpha$. Subsequently, activated Akt initiates translation of PSD-95 by removing the repression of the initiation factor $4 \mathrm{E}$-binding protein 1 (4E-BP1). Estradiol-mediated phosphorylation of cofilin has been shown to occur via activation of LIMK. Cofilin is an actin depolymerization factor and

depending on the stress history of the animal; while $\sim 200$ of the genes altered by CORT were the same irrespective of stress history, over 500 were different after a chronic stress exposure (Datson et al. 2013; Fig. 9). Together, these studies suggest that while the brain can recover, there remains considerable imprint of past stress experiences which alters future reactivity at the molecular level.

Yet a CORT challenge is not equivalent to replicating the complex network of pathways activated during an in vivo stress exposure. Expression profiles resulting from a bolus of corticosterone were found to be highly distinct from that of an acute stressor that elevates CORT (Gray et al. 2014; Fig. 9). While many of the well-established genes, such as c-Fos and Arc responded the same, there remains a widely unexplored set of new gene targets that have been identified, which are activated by stress, but function outside of traditional CORT or inflammatory signaling pathways.

\section{Epigenetic regulation: search for rapidly acting treatments}

Although the action of steroid hormones on cellular processes involves both genomic and non-genomic mechanisms of action, the cumulative actions of the interacting mediators result in changes in gene expression via epigenetic mechanisms involving histone it is inactivated by phosphorylation. Therefore, in the presence of estrogen, cofilin repression of actin polymerization is removed, resulting in an increase in filopodial density. The signal transduction pathways illustrated here are an oversimplification of a large body of work done in an in vitro cell line. Reproduced, with permission, from Dumitriu $D$, Rapp PR,

McEwen BS \& Morrison JH (2010) Estrogen and the aging brain: an elixir for the weary cortical network. Annals of the New York Academy of Sciences 1204 104-112. Copyright 2010 New York Academy of Sciences.

modifications, methylation of cytosine bases on DNA, and the regulatory actions of non-coding RNA's (Mehler 2008). Regarding histone modifications that either repress gene expression and DNA activity or enhance such activity, Reul and colleagues have shown that the forced swimminginduced behavioral immobility response requires histone H3 phospho-acetylation and c-Fos induction in distinct dentate granule neurons through recruitment of the NMDA/ERK/MSK 1/2 pathway (Chandramohan et al. 2008).

Another histone mark change in hippocampus, and most prominently in the dentate gyrus, is the dramatic induction by an acute restraint stress of trimethylation of lysine 9 on histone $\mathrm{H} 3$, which is associated with repression of a number of retrotransposon elements and reduction of the coding and non-coding RNA normally produced by the repressed DNA (Hunter et al. 2009). This repression is lost with repeated stress, suggesting the possibility that those retrotransposon elements may impair genomic stability under conditions of chronic stress (Hunter et al. 2014).

A current practical application of this is the investigation of rapidly acting antidepressants, because classical antidepressants work slowly and are not effective on every depressed individual. In the course of these studies, we are learning more about epigenetic mechanisms that connect excitatory amino acid function with neural remodeling and stress-related behaviors. One novel agent

Published by Bioscientifica Ltd 


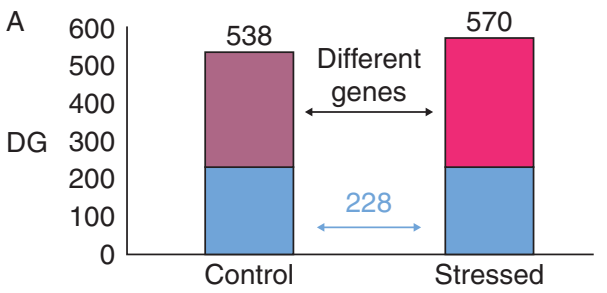

$6 \mathrm{~h}$ CORT treatment in naïve and CRS rats

B

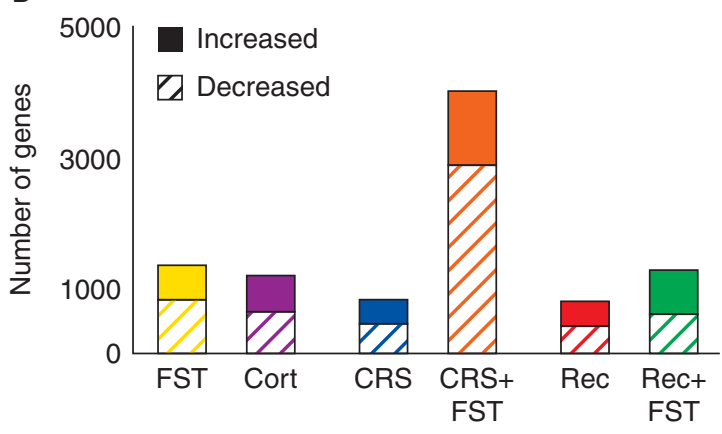

Figure 9

Effects of stress and acute glucocorticoid treatment on gene expression in hippocampus. (A) Naïve and $21 \mathrm{~d}$ chronically restraint stressed (CRS) rats respond differently to a $6 \mathrm{~h}$ bolus of corticosterone in which more than half of the genes turned on or turned off are different (Datson et al. 2013). (B) Naîve mice given acute forced swim stress (FST) show a largely different pattern of gene expression (up and down) from naïve mice given an acute corticosterone bolus. Moreover, mice that are either naïve, or $21 \mathrm{~d}$ CRS or $21 \mathrm{~d}$ CRS plus $21 \mathrm{~d}$ recovery respond, in large, differently to acute FST with respect to gene expression levels. There is a core of genes that always respond to the acute FST. Reproduced, with permission, from Gray JD, Rubin TG, Hunter RG \& McEwen BS 2014 Hippocampal gene expression changes underlying stress sensitization and recovery. Molecular Psychiatry 19 1171-1178. Copyright 2014, Rights Managed by Nature Publishing Group.

is acetyl-L-carnitine (LAC) that decreases depressive-like behavior within 3 days of treatment in a stress-induced and a genetic model of depression-like behavior while SSRI's and tricyclic drugs have no effect in that time frame (Nasca et al. 2013). Antidepressant effects of LAC have been shown in other animal models that mimic features of the spectrum of depressive disorders in humans (Cuccurazzu et al. 2013) and need to be expanded to human treatment resistant depression (Flight 2013, Russo \& Charney 2013). The rapid antidepressant action of LAC is mediated by acetylation of the histone H3K27 bound to the promoter gene of the metabotropic glutamate receptor, mGlu2, which inhibits glutamate release to the synapse (Fig. 10A). Furthermore, a single injection of the HDAC inhibitor, MS-275, mimicked the action of LAC in enhancing mGlu2 receptor expression in Flinders Sensitive Line (FSL) rats. Among other mechanisms, LAC also promotes acetylation of the p65, the major component of the NFkB transcription factor, to exert fast antidepressant responses (Cuccurazzu et al. 2013).
In the course of this work, we become aware that lower mGlu2 expression in hippocampus increases the vulnerability to stress (Nasca et al. 2014).

\section{Translation to the human brain}

The revelations about how acute and chronic stress affect the brain in animal models has been used by researchers and clinicians to show changes in function within the human brain that result from stress and trauma, and correspond to effects seen in the research on animal models (McEwen 2007, McEwen \& Gianaros 2011, McEwen \& Morrison 2013). These include changes in brain structure and functional activity in depression, post traumatic stress disorder (PTSD), Cushing's disease and type 2 diabetes, as well as effects of jet lag and shift work, chronic life stress, perceived stress and the beneficial effects of physical activity (Sheline 2003, McEwen \& Gianaros 2011). For perceived stress, medical students who had high scores on the ten item perceived stress scale showed impaired functional connectivity by fMRI in a brain circuit involving the prefrontal cortex, as well as impaired performance on a test of mental flexibility (Liston et al. 2009); these effects were reversed by a month vacation and we know from animal studies that prefrontal cortical and hippocampal dendrite shrinkage is reversible in young adult animals (Conrad et al. 1999, Radley et al. 2005). Regarding physical activity, previously sedentary older adults who walk an hour a day for 6 months to a year show enlargement of the hippocampal formation (Erickson et al. 2011) and this is likely due, at least in part, to the increased dentate gyrus neurogenesis that is stimulated by exercise and by an enriched environment (Kempermann et al. 1997, van Praag et al. 1999). It is also noteworthy that hippocampal volume increases with intense learning (Draganski et al. 2006), but is also decreased in Cushing's disease (Starkman et al. 1992).

However, there is age-related loss of resilience of the dendrite shrinkage in prefrontal cortex (Bloss et al. 2010), as well as age-related memory impairment, which, however, can be reduced by pharmacological intervention (Bloss et al. 2008, Pereira et al. 2014). These treatments may find their way into treating human mild cognitive impairment and perhaps also dementia.

Another translational application of structural plasticity and the actions of stress mediators is the somewhat surprising role of glucocorticoid elevation at the time of trauma in reducing the risk for PTSD (Schelling et al. 2004, Zohar et al. 2011, Rao et al. 2012). One possibility is that glucocorticoid stimulation of endocannabinoid production may be involved in this protection (Hill \& McEwen 2010).

Published by Bioscientifica Ltd 


\section{Individual differences, stressful early life events and the life course perspective}

What happens early in life determines the trajectory of development for the rest of the individual's life and biomedical science and medical practice are beginning to recognize this (Halfon et al. 2014). The original definition of epigenetics that referred to the emergence of characteristics of an organism with development (Waddington 1942) implied that there was no turning back, but that each stage of development offers possibilities to change the trajectory of brain and body function.

Adverse childhood experiences produce a lifelong vulnerability to mental and physical health disorders and prevention is paramount (Felitti et al. 1998, Shonkoff et al. 2009, Anda et al. 2010). Where adverse events have happened, it is important to find ways of compensatory remediation. This is an enormous challenge and the newer use of the term 'epigenetics', meaning 'above the genome' and referring to the ability to change expression of genetic traits via physical, behavioral and pharmacological intervention as previously described, offers some hope that the brain and body remain dynamic over the lifespan (Bavelier et al. 2010, McEwen 2012).

Even without adversity in childhood, individuals with the same genes turn out differently and this is reflected in divergent epigenetic profiles of $\mathrm{CpG}$ methylation patters of chromosomes of identical twins as they age (Fraga et al. 2005). Cloned mice raised in an enriched environment develop differences in locomotor activity correlated with levels of dentate gyrus neurogenesis (Freund et al. 2013). And genetically similar rats screened for anxiety-like behavior early in life show consistent individual anxiety profiles over their life course, and the more anxious rats die 200 days sooner than the less anxious ones (Cavigelli \& McClintock 2003, Cavigelli et al. 2006). Reduced prefrontal cortical dendrite length and branching is a neuroanatomical feature of elevated anxiety-like behavior in rats (Miller et al. 2012).

Arising out of the studies of the antidepressant-like actions of LAC is new insight into at least one possible mechanism involving mineralocorticoid receptors (MR) in hippocampus by which individual differences arise in susceptibility to stressors for developing anxiety- and depressive-like behaviors. Mice with a mGlu2 knock-out subjected to chronic unpredictable stressors show more signs of coat deterioration, reduced body weight and increased immobility at the forced swim test compared to WT animals subjected to the same regimen of stress (Nasca et al. 2014). In WT mice, a simple light-dark test revealed a subset with higher anxiety that have elevated hippocampal MR. Those mice with higher MR showed a greater stressinduced reduction in mGlu2 accompanied by more anxiety and depressive-like behaviors; this effect is mediated by a
(A)

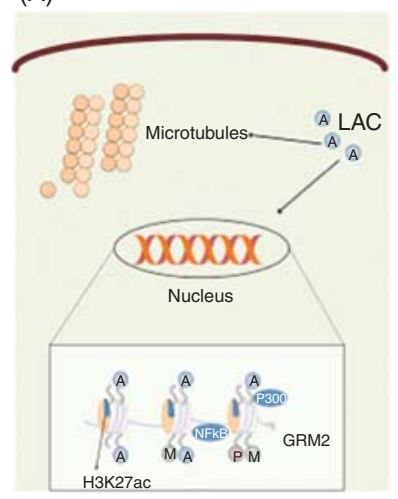

(B)

Naïve

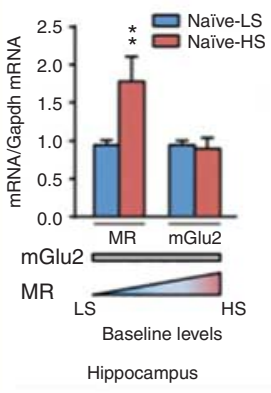

Stress

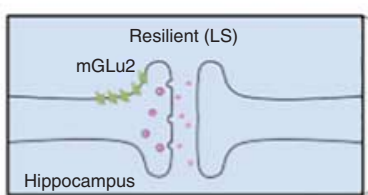

Epigenetic allostasis

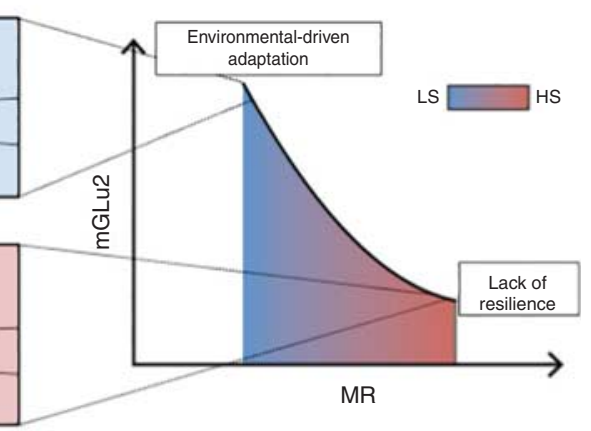

\section{Figure 10}

Novel mechanisms for rapidly acting medications to treat stress-related disorders. (A) The novel antidepressant candidate acetyl-L-carnitine (LAC) may act inside and outside the nucleus to exert fast antidepressant responses: it has been shown that LAC corrects mGlu2 deficits in vulnerable animal models by increasing acetylation of either the histone $\mathrm{H} 3 \mathrm{~K} 27$ bound to Grm2 promoter gene or the NFkB-p65 member (Nasca et al. 2013).

(B) The use of the light-dark test as a screening method allows identification of clusters of animals with a different baseline susceptibility along with differences in mineralocorticoid receptor (MR) levels in hippocampus. The susceptible mice (HS, high susceptible) that are characterized by higher baseline MR levels show reduced hippocampal mGlu2 expression associated with exacerbation of anxious and of depressive-like behaviors after acute and chronic stress respectively. Conversely, individuals (LS, low susceptible) with lower baseline MR levels cope better with stress and show adaptation in mGlu2 receptor expression in hippocampus. The epigenetic allostasis model points to the developmental origins of these individual differences, suggesting that unknown epigenetic influences early in life may lead to alterations in MR hippocampal levels. Reproduced, with permission, from Nasca C, Bigio B, Zelli D, Nicoletti F \& McEwen BS (2014) Mind the gap: glucocorticoids modulate hippocampal glutamate tone underlying individual differences in stress susceptibility. Molecular Psychiatry 20 755-763. Copyright 2014, Rights Managed by Nature Publishing Group. 
stress-induced reduction of the epigenetic enzyme P300, which regulates acetylation of the histone H3K27 that promotes mGlu2 expression (Nasca et al. 2014).

The ability of MR activation to mediate enhanced anxiety and depression-like behavior after acute and chronic stress by down-regulating mGlu2 is consistent with evidence showing a role of MR in anxiety-like behavior (Korte et al. 1995) in hippocampus (Smythe et al. 1997, Bitran etal. 1998) and particularly the ventral hippocampus (McEown \& Treit 2011). Despite high baseline cortisol levels, patients with major depression show high functional activity of the MR system along with decreased sensitivity to GR agonists, suggesting an imbalance in the MR/GR ratio (Young et al. 2003). Indeed, the MR/GR balance is important not only for emotional regulation but also for cognitive function and HPA regulation (de Kloet 2014).

The epigenetic allostasis model in Fig. 10 proposes that early-life epigenetic influences, program each individual to different trajectories of behavioral and physiological responses to later stressful life events, and it remains to be determined whether the higher MR-levels reflect epigenetic influences of maternal care or other experiences early in life. Indeed, the role of consistent and disrupted maternal care, as well as prenatal stress, have been investigated in animal models and should be considered (Francis et al. 1999, Weinstock 2005, Moriceau \& Sullivan 2006, Maccari \& Morley-Fletcher 2007, Akers et al. 2008, Molet et al. 2014).

\section{Impact of the social environment}

The emerging field of epigenetics, along with the reversible remodeling of brain architecture, has provided a new way of conceptualizing the influence of the social and physical environment on the brain and body. As shown in Fig. 4, the brain is the central organ of stress and adaptation because it determines what is threatening and, therefore, stressful. And the brain controls autonomic and neuroendocrine signals that affect the rest of the body to promote adaptation ('allostasis') and also allostatic load and overload (McEwen \& Stellar 1993, McEwen 1998, McEwen \& Wingfield 2003). Health behaviors ('lifestyle'), including choice and amount of food intake, smoking, alcohol intake, physical activity, or lack thereof, and social interactions also feed into and contribute to allostasis and allostatic load/overload (McEwen 2006). Finally, the genetic endowment and experiential factors throughout the life course, but especially early in life, influence the trajectory of brain and body function (Danese \& McEwen 2012, Halfon et al. 2014).
Low socioeconomic status is associated with increased risk for the common diseases of modern life and is associated with increased inflammatory tone and altered white matter structure (Seeman et al. 2010, Gianaros et al. 2013). Likewise, type 2 diabetes, which is more common at lower levels of socioeconomic status (SES), is also associated with altered myelin and impaired cognitive function (Yau et al. 2012). On the positive side, meaning and purpose in life appear to have a considerable ability to promote health and ward off cognitive decline, including dementia (Carlson et al. 2009, Boyle et al . 2010). Likewise, regular physical activity has many benefits for brain and body health (Colcombe et al. 2004).

\section{Conclusions}

With the discovery of circulating hormone actions throughout the brain on virtually every aspect of brain function, the original definition of 'neuroendocrinology' based upon the work of Geoffrey Harris has expanded to encompass many aspects of reciprocal brain-body communication. With the new appreciation of the life-course perspective for human health and disease, along with the emerging field of gene $x$ environment interactions now called 'epigenetics' (Halfon et al. 2014), the reciprocal communication between the brain and body via hormonal and neural mediators takes a central role in facilitating progress in understanding how the social and physical environment 'gets under the skin' to alter trajectories of health and disease. Given the central role of the brain, there is now impetus for interventions that involve policies of government and the private sector, as well as psychosocial interventions at the individual level that produce a 'top-down' improvement in the physiological processes that are dysregulated by stress and adversity (Acheson 1998). The emerging recognition of the ability of the brain to change its architecture and function via these top-down interventions involving brain-body communication, where pharmaceutical agents or behavioral interventions that open up 'windows of plasticity,' gives hope for redirecting individual trajectories towards better physical and mental health.

\section{Declaration of interest}

The authors declare that there is no conflict of interest that could be perceived as prejudicing the impartiality of this review.

\section{Funding}

Research is supported by RO1 MH41256 from NIH, by the Hope for Depression Research Foundation and by the American Foundation for Suicide Prevention to C N and NRSA Award \#F32 MH102065 to J D G.

Published by Bioscientifica Ltd 


\section{References}

Acheson SD 1998 Independent Inquiry into Inequalities in Health Report. London, UK: The Stationary Office.

Ahima RS \& Harlan RE 1990 Charting of type II glucocorticoid receptor-like immunoreactivity in the rat central nervous system. Neuroscience 39 579-604. (doi:10.1016/0306-4522(90)90244-X)

Ahima R, Krozowski Z \& Harlan R 1991 Type I corticosteroid receptor-like immunoreactivity in the rat CNS: distribution and regulation by corticosteroids. Journal of Comparative Neurology 313 522-538. (doi:10.1002/cne.903130312)

Akers KG, Yang Z, DelVecchio DP, Reeb BC, Romeo RD, McEwen BS \& Tang AC 2008 Social competitiveness and plasticity of neuroendocrine function in old age: influence of neonatal novelty exposure and maternal care reliability. PLoS ONE 3(7) e2840. (doi:10.1371/journal. pone.0002840)

Altman J 1962 Are new neurons formed in the brains of adult mammals? Science 135 1127-1128. (doi:10.1126/science.135.3509.1127)

Alvarez-Buylla A \& Garcia-Verdugo JM 2002 Neurogenesis in adult subventricular zone. Journal of Neuroscience 22 629-634.

Anda RF, Butchart A, Felitti VJ \& Brown DW 2010 Building a framework for global surveillance of the public health implications of adverse childhood experiences. American Journal of Preventive Medicine 39 93-98. (doi:10.1016/j.amepre.2010.03.015)

Arendt T, Stieler J, Strijkstra AM, Hut RA, Rudiger J, Van der Zee EA, Harkany T, Holzer M \& Härtig W 2003 Reversible paired helical filament-like phosphorylation of tau is an adaptive process associated with neuronal plasticity in hibernating animals. Journal of Neuroscience 23 6972-6981.

Bavelier D, Levi DM, Li RW, Dan Y \& Hensch TK 2010 Removing brakes on adult brain plasticity: from molecular to behavioral interventions. Journal of Neuroscience 30 14964-14971. (doi:10.1523/JNEUROSCI. 4812-10.2010)

Biegler R, McGregor A, Krebs JR \& Healy SD 2001 A larger hippocampus is associated with longer-lasting spatial memory. PNAS 98 6941-6944. (doi:10.1073/pnas.121034798)

Bitran D, Shiekh M, Dowd JA, Dugan MM \& Renda P 1998 Corticosterone is permissive to the anxiolytic effect that results from the blockade of hippocampal mineralocorticoid receptors. Pharmacology, Biochemistry, and Behavior 60 879-887. (doi:10.1016/S00913057(98)00071-9)

Bloss EB, Hunter RG, Waters EM, Munoz C, Bernard K \& McEwen BS 2008 Behavioral and biological effects of chronic S18986, a positive AMPA receptor modulator, during aging. Experimental Neurology 210 109-117. (doi:10.1016/j.expneurol.2007.10.007)

Bloss EB, Janssen WG, McEwen BS \& Morrison JH 2010 Interactive effects of stress and aging on structural plasticity in the prefrontal cortex. Journal of Neuroscience 30 6726-6731. (doi:10.1523/JNEUROSCI.075910.2010)

Boyle PA, Buchman AS, Barnes LL \& Bennett DA 2010 Effect of a purpose in life on risk of incident Alzheimer disease and mild cognitive impairment in community-dwelling older persons. Archives of General Psychiatry 67 304-310. (doi:10.1001/archgenpsychiatry.2009.208)

Brinton RD 2008 The healthy cell bias of estrogen action: mitochondrial bioenergetics and neurological implications. Trends in Neurosciences $\mathbf{3 1}$ 529-537. (doi:10.1016/j.tins.2008.07.003)

Burger DK, Saucier JM, Iwaniuk AN \& Saucier DM 2013 Seasonal and sex differences in the hippocampus of a wild rodent. Behavioural Brain Research 236 131-138. (doi:10.1016/j.bbr.2012.08.044)

Cameron HA \& Gould E 1994 Adult neurogenesis is regulated by adrenal steroids in the dentate gyrus. Neuroscience 61 203-209. (doi:10.1016/ 0306-4522(94)90224-0)

Cameron HA \& Dayer AG 2008 New interneurons in the adult neocortex: small, sparse, but significant? Biological Psychiatry 63 650-655. (doi:10.1016/j.biopsych.2007.09.023)
Carlson MC, Erickson KI, Kramer AF, Voss MW, Bolea N, Mielke M, McGill S, Rebok GW, Seeman T \& Fried LP 2009 Evidence for neurocognitive plasticity in at-risk older adults: the experience corps program. The Journals of Gerontology. Series A, Biological Sciences and Medical Sciences 64 1275-1282. (doi:10.1093/gerona/glp117)

Cavigelli SA \& McClintock MK 2003 Fear of novelty in infant rats predicts adult corticosterone dynamics and an early death. PNAS $\mathbf{1 0 0}$ 16131-16136. (doi:10.1073/pnas.2535721100)

Cavigelli SA, Yee JR \& McClintock MK 2006 Infant temperament predicts life span in female rats that develop spontaneous tumors. Hormones and Behavior 50 454-462. (doi:10.1016/j.yhbeh.2006.06.001)

Chandramohan Y, Droste SK, Arthur JS \& Reul JM 2008 The forced swimming-induced behavioural immobility response involves histone H3 phospho-acetylation and c-Fos induction in dentate gyrus granule neurons via activation of the $N$-methyl-D-aspartate/extracellular signalregulated kinase/mitogen- and stress-activated kinase signalling pathway. European Journal of Neuroscience 27 2701-2713. (doi:10.1111/ j.1460-9568.2008.06230.x)

Chen Y, Fenoglio KA, Dube CM, Grigoriadis DE \& Baram TZ 2006a Cellular and molecular mechanisms of hippocampal activation by acute stress are age-dependent. Molecular Psychiatry 11 992-1002.

Chen Z-Y, Jing D, Bath KG, Ieraci A, Khan T, Siao CJ, Herrera DG, Toth M, Yang C \& McEwen BS $2006 b$ Genetic variant BDNF (Val66Met) polymorphism alters anxiety-related behavior. Science 314 140-143. (doi:10.1126/science.1129663)

Clayton NS 2001 Hippocampal growth and maintenance depend on food-caching experience in juvenile mountain chickadees (Poecile gambeli). Behavioral Neuroscience 115 614-625. (doi:10.1037/07357044.115.3.614)

Colcombe SJ, Kramer AF, McAuley E, Erickson KI \& Scalf P 2004 Neurocognitive aging and cardiovascular fitness. Journal of Molecular Neuroscience 24 9-14. (doi:10.1385/JMN:24:1:009)

Conrad CD, Magarinos AM, LeDoux JE \& McEwen BS 1999 Repeated restraint stress facilitates fear conditioning independently of causing hippocampal CA3 dendritic atrophy. Behavioral Neuroscience $\mathbf{1 1 3}$ 902-913. (doi:10.1037/0735-7044.113.5.902)

Cuccurazzu B, Bortolotto V, Valente MM, Ubezio F, Koverech A, Canonico PL \& Grilli M 2013 Upregulation of mGlu2 receptors via NF- $\mathrm{B}$ p65 acetylation is involved in the proneurogenic and antidepressant effects of acetyl-L-carnitine. Neuropsychopharmacology 38 2220-2230. (doi:10.1038/npp.2013.121)

Danese A \& McEwen BS 2012 Adverse childhood experiences, allostasis, allostatic load, and age-related disease. Physiology \& Behavior 106 29-39. (doi:10.1016/j.physbeh.2011.08.019)

Daniel JM \& Dohanich GP 2001 Acetylcholine mediates the estrogeninduced increase in NMDA receptor binding in CA1 of the hippocampus and the associated improvement in working memory. Journal of Neuroscience 21 6949-6956.

Datson NA, van den Oever JM, Korobko OB, Magarinos AM, de Kloet ER \& McEwen BS 2013 Previous history of chronic stress changes the transcriptional response to glucocorticoid challenge in the dentate gyrus region of the male rat hippocampus. Endocrinology $\mathbf{1 5 4}$ 3261-3272. (doi:10.1210/en.2012-2233)

Derntl B, Finkelmeyer A, Eickhoff S, Kellermann T, Falkenberg DI, Schneider F \& Habel U 2010 Multidimensional assessment of empathic abilities: neural correlates and gender differences. Psychoneuroendocrinology 35 67-82. (doi:10.1016/j.psyneuen.2009.10.006)

Diamond DM, Bennett MC, Fleshner M \& Rose GM 1992 Inverted-U relationship between the level of peripheral corticosterone and the magnitude of hippocampal primed burst potentiation. Hippocampus $\mathbf{2}$ 421-430. (doi:10.1002/hipo.450020409)

Dickens M, Romero LM, Cyr NE, Dunn IC \& Meddle SL 2009 Chronic stress alters glucocorticoid receptor and mineralocorticoid receptor mRNA expression in the European starling (Sturnus vulgaris) brain. Journal of Neuroendocrinology 21 832-840. (doi:10.1111/j.13652826.2009.01908.x) 
Draganski B, Gaser C, Kempermann G, Kuhn HG, Winkler J, Büchel C \& May A 2006 Temporal and spatial dynamics of brain structure changes during extensive learning. Journal of Neuroscience 26 6314-6317. (doi:10.1523/JNEUROSCI.4628-05.2006)

Du J, McEwen BS \& Manji HK 2009a Glucocorticoid receptors modulate mitochondrial function. Communicative \& Integrative Biology 2 1-3. (doi:10.4161/cib.2.4.8554)

Du J, Wang Y, Hunter R, Wei Y, Blumenthal R, Falke C, Khairova R, Zhou R, Yuan P \& Machado-Vieira R $2009 b$ Dynamic regulation of mitochondrial function by glucocorticoids. PNAS 106 3543-3548. (doi:10.1073/pnas.0812671106)

Dumitriu D, Rapp PR, McEwen BS \& Morrison JH 2010 Estrogen and the aging brain: an elixir for the weary cortical network. Annals of the New York Academy of Sciences 1204 104-112. (doi:10.1111/j.1749-6632. 2010.05529.x)

Erickson KI, Voss MW, Prakash RS, Basak C, Szabo A, Chaddock L, Kim JS, Heo S, Alves H \& White SM 2011 Exercise training increases size of hippocampus and improves memory. PNAS 108 3017-3022. (doi:10.1073/pnas.1015950108)

Felitti VJ, Anda RF, Nordenberg D, Williamson DF, Spitz AM, Edwards V, Koss MP \& Marks JS 1998 Relationship of childhood abuse and household dysfunction to many of the leading causes of death in adults. The adverse childhood experiences (ACE) study. American Journal of Preventive Medicine 14 245-258. (doi:10.1016/S0749. 3797(98)00017-8)

Flight MH 2013 Antidepressant epigenetic action. Nature Reviews. Neuroscience 14 226. (doi:10.1038/nrn3466)

Fraga MF, Ballestar E, Paz MF, Ropero S, Setien F, Ballestar ML, Heine-Suñer D, Cigudosa JC, Urioste M \& Benitez J 2005 Epigenetic differences arise during the lifetime of monozygotic twins. PNAS 102 10604-10609. (doi:10.1073/pnas.0500398102)

Francis D, Diorio J, Liu D \& Meaney MJ 1999 Nongenomic transmission across generations of maternal behavior and stress responses in the rat. Science 286 1155-1158. (doi:10.1126/science.286.5442.1155)

Frankfurt M, Gould E, Wolley C \& McEwen BS 1990 Gonadal steroids modify dendritic spine density in ventromedial hypothalamic neurons: a golgi study in the adult rat. Neuroendocrinology $\mathbf{5 1} 530-535$. (doi:10.1159/000125387)

Freund J, Brandmaier AM, Lewejohann L, Kirste I, Kritzler M, Krüger A, Sachser N, Lindenberger U \& Kempermann G 2013 Emergence of individuality in genetically identical mice. Science 340 756-759. (doi:10.1126/science.1235294)

Galea LAM, McEwen BS, Tanapat P, Deak T, Spencer RL \& Dhabhar FS 1997 Sex differences in dendritic atrophy of CA3 pyramidal neurons in response to chronic restraint stress. Neuroscience 81 689-697. (doi:10.1016/S0306-4522(97)00233-9)

Gerlach J \& McEwen BS 1972 Rat brain binds adrenal steroid hormone: radioautography of hippocampus with corticosterone. Science 175 1133-1136. (doi:10.1126/science.175.4026.1133)

Gerlach J, McEwen BS, Pfaff DW, Moskovitz S, Ferin M \& Waters EM 1976 Cells in regions of rhesus monkey brain and pituitary retain radioactive estradiol, corticosterone and cortisol differently. Brain Research 103 603-612. (doi:10.1016/0006-8993(76)90463-7)

Gianaros PJ, Marsland AL, Sheu LK, Erickson KI \& Verstynen TD 2013 Inflammatory pathways link socioeconomic inequalities to white matter architecture. Cerebral Cortex 23 2058-2071. (doi:10.1093/ cercor/bhs191)

Gould E 2007 How widespread is adult neurogenesis in mammals? Nature Reviews. Neuroscience 8 481-488. (doi:10.1038/nrn2147)

Gould E, McEwen BS, Tanapat P, Galea LAM \& Fuchs E 1997 Neurogenesis in the dentate gyrus of the adult tree shrew is regulated by psychosocial stress and NMDA receptor activation. Journal of Neuroscience 17 2492-2498.

Gould E, Tanapat P, McEwen BS, Flugge G \& Fuchs E 1998 Proliferation of granule cell precursors in the dentate gyrus of adult monkeys is diminished by stress. PNAS 95 3168-3171. (doi:10.1073/ pnas.95.6.3168)
Govindarajan A, Rao BSS, Nair D, Trinh M, Mawjee N, Tonegawa S \& Chattarji S 2006 Transgenic brain-derived neurotrophic factor expression causes both anxiogenic and antidepressant effects. PNAS 103 13208-13213. (doi:10.1073/pnas.0605180103)

Goy R \& McEwen BS, Eds 1980 Sexual Differentiation of the Brain. Cambridge, MA, USA: MIT Press

Gray JD, Rubin TG, Hunter RG \& McEwen BS 2014 Hippocampal gene expression changes underlying stress sensitization and recovery. Molecular Psychiatry 19 1171-1178. (doi:10.1038/mp.2013.175)

Guillemin R 1978 Peptides in the brain: the new endocrinology of the neuron. Science 202 390-402. (doi:10.1126/science.212832)

Halfon N, Larson K, Lu M, Tullis E \& Russ S 2014 Lifecourse health development: past, present and future. Maternal and Child Health Journal 18 344-365. (doi:10.1007/s10995-013-1346-2)

Harris GW 1970 Effects of the nervous system on the pituitary-adrenal activity. Progress in Brain Research 32 86-88.

Harris GW \& Levine S 1965 Sexual differentiation of the brain and its experimental control. Journal of Physiology 181 379-400. (doi:10.1113/ jphysiol.1965.sp007768)

Hill MN \& McEwen BS 2010 Involvement of the endocannabinoid system in the neurobehavioural effects of stress and glucocorticoids. Progress in Neuro-Psychopharmacology \& Biological Psychiatry 34 791-797. (doi:10.1016/j.pnpbp.2009.11.001)

Hill MN, Hillard CJ \& McEwen BS 2011a Alterations in corticolimbic dendritic morphology and emotional behavior in cannabinoid CB1 receptor-deficient mice parallel the effects of chronic stress. Cerebral Cortex 21 2056-2064. (doi:10.1093/cercor/bhq280)

Hill MN, McLaughlin RJ, Pan B, Fitzgerald ML, Roberts CJ, Lee TT, Karatsoreos IN, Mackie K, Viau V \& Pickel VM $2011 b$ Recruitment of prefrontal cortical endocannabinoid signaling by glucocorticoids contributes to termination of the stress response. Journal of Neuroscience 31 10506-10515. (doi:10.1523/JNEUROSCI.0496-11.2011)

Hill MN, Kumar SA, Filipski SB, Iverson M, Stuhr KL, Keith JM, Cravatt BF, Hillard CJ, Chattarji S \& McEwen BS 2013 Disruption of fatty acid amide hydrolase activity prevents the effects of chronic stress on anxiety and amygdalar microstructure. Molecular Psychiatry 18 1125-1135. (doi:10.1038/mp.2012.90)

Hunter RG, McCarthy KJ, Milne TA, Pfaff DW \& McEwen BS 2009 Regulation of hippocampal H3 histone methylation by acute and chronic stress. PNAS 106 20912-20917. (doi:10.1073/pnas. 0911143106)

Hunter RG, Gagnidze K, McEwen BS \& Pfaff DW 2015 Stress and the dynamic genome: steroids, epigenetics, and the transposome. PNAS 112 6828-6833. (doi:10.1073/pnas.1411260111)

Jensen E \& Jacobson H 1962 Basic guides to the mechanism of estrogen action. Recent Progress in Hormone Research 18 387-408.

Joels M 2006 Corticosteroid effects in the brain: U-shape it. Trends in Pharmacological Sciences 27 244-250. (doi:10.1016/j.tips.2006.03.007)

Kaplan MS 2001 Environment complexity stimulates visual cortex neurogenesis: death of a dogma and a research career. Trends in Neurosciences 24 617-620. (doi:10.1016/S0166-2236(00)01967-6)

Karst H, Berger S, Turiault M, Tronche F, Schutz G \& Joels M 2005 Mineralocorticoid receptors are indispensable for nongenomic modulation of hippocampal glutamate transmission by corticosterone. PNAS 102 19204-19207. (doi:10.1073/pnas.0507572102)

Kempermann G, Kuhn HG \& Gage FH 1997 More hippocampal neurons in adult mice living in an enriched environment. Nature 586 493-495. (doi:10.1038/386493a0)

de Kloet ER 2014 From receptor balance to rational glucocorticoid therapy. Endocrinology 155 2754-2769. (doi:10.1210/en.2014-1048)

Korte SM, de Boer SF, de Kloet ER \& Bohus B 1995 Anxiolytic-like effects of selective mineralocorticoid and glucocorticoid antagonists on fearenhanced behavior in the elevated plus-maze. Psychoneuroendocrinology 20 385-394. (doi:10.1016/0306-4530(94)00069-7)

Ledoux VA, Smejkalova T, May RM, Cooke BM \& Woolley CS 2009 Estradiol facilitates the release of neuropeptide $\mathrm{Y}$ to suppress 
hippocampus-dependent seizures. Journal of Neuroscience 29 1457-1468. (doi:10.1523/JNEUROSCI.4688-08.2009)

Leranth C, Petnehazy O \& MacLusky NJ 2003 Gonadal hormones affect spine synaptic density in the CA1 hippocampal subfield of male rats. Journal of Neuroscience 23 1588-1592.

Leuner B, Glasper ER \& Gould E 2010 Sexual experience promotes adult neurogenesis in the hippocampus despite an initial elevation in stress hormones. PLOS ONE 5 e11597. (doi:10.1371/journal.pone.0011597)

Leuner B, Caponiti JM \& Gould E 2012 Oxytocin stimulates adult neurogenesis even under conditions of stress and elevated glucocorticoids. Hippocampus 22 861-868. (doi:10.1002/hipo.20947)

Lewis C, McEwen BS \& Frankfurt M 1995 Estrogen-induction of dendritic spines in ventromedial hypothalamus and hippocampus: effects of neonatal aromatase blockade and adult castration. Developmental Brain Research 87 91-95. (doi:10.1016/0165-3806(95)00052-F)

Liston C \& Gan WB 2011 Glucocorticoids are critical regulators of dendritic spine development and plasticity in vivo. PNAS 108 16074-16079. (doi:10.1073/pnas.1110444108)

Liston C, McEwen BS \& Casey BJ 2009 Psychosocial stress reversibly disrupts prefrontal processing and attentional control. PNAS 106 912-917. (doi:10.1073/pnas.0807041106)

Liston C, Cichon JM, Jeanneteau F, Jia Z, Chao MV \& Gan WB 2013 Circadian glucocorticoid oscillations promote learning-dependent synapse formation and maintenance. Nature Neuroscience 16 698-705. (doi:10.1038/nn.3387)

Loy R, Gerlach J \& McEwen BS 1988 Autoradiographic localization of estradiol-binding neurons in rat hippocampal formation and entorhinal cortex. Developmental Brain Research 39 245-251. (doi:10.1016/ 0165-3806(88)90028-4)

Maccari S \& Morley-Fletcher S 2007 Effects of prenatal restraint stress on the hypothalamus-pituitary-adrenal axis and related behavioural and neurobiological alterations. Psychoneuroendocrinology 32 S10-S15. (doi:10.1016/j.psyneuen.2007.06.005)

Magarinos AM, McEwen BS, Saboureau M \& Pevet P 2006 Rapid and reversible changes in intrahippocampal connectivity during the course of hibernation in European hamsters. PNAS 103 18775-18780. (doi:10.1073/pnas.0608785103)

Magarinos AM, Li CJ, GalToth J, Bath KG, Jing D, Lee FS \& McEwen BS 2011 Effect of brain-derived neurotrophic factor haploinsufficiency on stress-induced remodeling of hippocampal neurons. Hippocampus $\mathbf{2 1}$ 253-264. (doi:10.1002/hipo.20744)

Maguire EA, Frackowiak RSJ \& Frith CD 1997 Recalling routes around London: activation of the right hippocampus in taxi drivers. Journal of Neuroscience 17 7103-7110.

Maier SF \& Watkins LR 1998 Cytokines for psychologists: Implications of bidirectional immune-to-brain communication for understanding behavior, mood, and cognition. Psychological Review 105 83-107. (doi:10.1037/0033-295X.105.1.83)

McEown K \& Treit D 2011 Mineralocorticoid receptors in the medial prefrontal cortex and hippocampus mediate rats' unconditioned fear behaviour. Hormones and Behavior 60 581-588. (doi:10.1016/j.yhbeh. 2011.08.007)

McEwen BS 1976 Steroid hormone receptors in developing and mature brain tissue. In Neurotransmitters, Hormones and Receptors: Novel Approaches, pp. 50-66. Eds S Snyder \& BS McEwen. Bethesda, MA, USA: Society of Neuroscience.

McEwen BS 1998 Protective and damaging effects of stress mediators. New England Journal of Medicine 338 171-179. (doi:10.1056/ NEJM199801153380307)

McEwen BS 1999 Stress and hippocampal plasticity. Annual Review of Neuroscience 22 105-122. (doi:10.1146/annurev.neuro.22.1.105)

McEwen BS 2006 Protective and damaging effects of stress mediators: central role of the brain. Dialogues in Clinical Neuroscience 8 367-381.

McEwen BS 2007 Physiology and neurobiology of stress and adaptation: central role of the brain. Physiological Reviews 87 873-904. (doi:10.1152/ physrev.00041.2006)
McEwen BS 2010 Stress, sex, and neural adaptation to a changing environment: mechanisms of neuronal remodeling. Annals of the New York Academy of Sciences 1204 (Suppl) E38-E59. (doi:10.1111/j. 1749-6632.2010.05568.x)

McEwen BS 2012 Brain on stress: how the social environment gets under the skin. PNAS 109 (Suppl 2) 17180-17185. (doi:10.1073/ pnas.1121254109)

McEwen BS \& Plapinger L 1970 Association of corticosterone-1,2 3H with macromolecules extracted from brain cell nuclei. Nature 226 263-264. (doi:10.1038/226263a0)

McEwen BS \& Stellar E 1993 Stress and the individual. Mechanisms leading to disease. Archives of Internal Medicine 153 2093-2101. (doi:10.1001/ archinte.1993.00410180039004)

McEwen BS \& Wingfield JC 2003 The concept of allostasis in biology and biomedicine. Hormones and Behavior 43 2-15. (doi:10.1016/S0018506X(02)00024-7)

McEwen BS \& Chattarji S 2007 Neuroendocrinology of stress. In Handbook of Neurochemistry and Molecular Neurobiology, pp. 572-593. New York, NY, USA: Springer-Verlag.

McEwen BS \& Milner TA 2007 Hippocampal formation: shedding light on the influence of sex and stress on the brain. Brain Research Reviews $\mathbf{5 5}$ 343-355. (doi:10.1016/j.brainresrev.2007.02.006)

McEwen BS \& Gianaros PJ 2011 Stress- and allostasis-induced brain plasticity. Annual Review of Medicine 62 431-445. (doi:10.1146/ annurev-med-052209-100430)

McEwen BS \& Morrison JH 2013 The brain on stress: vulnerability and plasticity of the prefrontal cortex over the life course. Neuron 79 16-29. (doi:10.1016/j.neuron.2013.06.028)

McEwen BS, Weiss J \& Schwartz L 1968 Selective retention of corticosterone by limbic structures in rat brain. Nature 220 911-912. (doi:10.1038/ 220911a0)

McEwen BS, Lieberburg I, Chaptal C \& Krey L 1977 Aromatization: important for sexual differentiation of the neonatal rat brain. Hormones and Behavior 9 249-263. (doi:10.1016/0018-506X(77)90060-5)

McEwen BS, Gould E, Orchinik M, Weiland NG \& Woolley CS 1995 Oestrogens and the structural and functional plasticity of neurons: implications for memory, ageing and neurodegenerative processes. In Ciba Foundation Symposium \#191 The Non-reproductive Actions of Sex Steroids, pp 52-73. Ed. J Goode. London: CIBA Foundation.

McEwen B, Akama K, Alves S, Brake WG, Bulloch K, Lee S, Li C, Yuen G \& Milner TA 2001 Tracking the estrogen receptor in neurons: implications for estrogen-induced synapse formation. PNAS 98 7093-7100. (doi:10.1073/pnas.121146898)

Mehler MF 2008 Epigenetic principles and mechanisms underlying nervous system functions in health and disease. Progress in Neurobiology 86 305-341. (doi:10.1016/j.pneurobio.2008.10.001)

Meites J 1992 Short history of neuroendocrinology and the International Society of Neuroendocrinology. Neuroendocrinology 56 1-10. (doi:10.1159/000126201)

Miller MM, Morrison JH \& McEwen BS 2012 Basal anxiety-like behavior predicts differences in dendritic morphology in the medial prefrontal cortex in two strains of rats. Behavioural Brain Research 229 280-288. (doi:10.1016/j.bbr.2012.01.029)

Milner TA, McEwen BS, Hayashi S, Li CJ, Reagen L \& Alves SE 2001 Ultrastructural evidence that hippocampal $\alpha$ estrogen receptors are located at extranuclear sites. Journal of Comparative Neurology 429 355-371. (doi:10.1002/1096-9861(20010115)429:3 <355::AID-CNE1> 3.0.CO;2-)

Molet J, Maras PM, Avishai-Eliner S \& Baram TZ 2014 Naturalistic rodent models of chronic early-life stress. Developmental Psychobiology 56 1675-1688. (doi:10.1002/dev.21230)

Moriceau S \& Sullivan R 2006 Maternal presence serves as a switch between learning fear and attraction in infancy. Nature Neuroscience $\mathbf{8}$ 1004-1006. (doi:10.1038/nn1733)

Moutsatsou P, Psarra A-MG, Tsiapara A, Paraskevakou H, Davaris P \& Sekeris CE 2001 Localization of the glucocorticoid receptor in rat brain

Published by Bioscientifica Ltd 
mitochondria. Archives of Biochemistry and Biophysics 386 69-78. (doi:10.1006/abbi.2000.2162)

Mucha M, Skrzypiec AE, Schiavon E, Attwood BK, Kucerova E \& Pawlak R 2011 Lipocalin-2 controls neuronal excitability and anxiety by regulating dendritic spine formation and maturation. PNAS $\mathbf{1 0 8}$ 18436-18441. (doi:10.1073/pnas.1107936108)

Nacher J, Guirado R \& Castillo-Gomez E 2013 Structural plasticity of interneurons in the adult brain: role of PSA-NCAM and implications for psychiatric disorders. Neurochemical Research 38 1122-1133. (doi:10.1007/s11064-013-0977-4)

Naftolin F 1994 Brain aromatization of androgens. Journal of Reproductive Medicine 39 257-261.

Naftolin F, Ryan KJ \& Petro Z 1971 Aromatization of androstenedione by limbic system tissue from human foetuses. Journal of Endocrinology $\mathbf{5 1}$ 795-796. (doi:10.1677/joe.0.0510795)

Nasca C, Xenos D, Barone Y, Caruso A, Scaccianoce S, Matrisciano F, Battaglia G, Mathé AA, Pittaluga A \& Lionetto L 2013 L-acetylcarnitine causes rapid antidepressant effects through the epigenetic induction of mGlu2 receptors. PNAS 110 4804-4809. (doi:10.1073/pnas. 1216100110)

Nasca C, Bigio B, Zelli D, Nicoletti F \& McEwen BS 2015 Mind the gap: glucocorticoids modulate hippocampal glutamate tone underlying individual differences in stress susceptibility. Molecular Psychiatry 20 755-763.

Nilsen J, Irwin RW, Gallaher TK \& Diaz Brinton R 2007 Estradiol in vivo regulation of brain mitochondrial proteome. Journal of Neuroscience $\mathbf{2 7}$ 14069-14077. (doi:10.1523/JNEUROSCI.4391-07.2007)

Nottebohm F 2002 Neuronal replacement in adult brain. Brain research Bulletin 57 737-749. (doi:10.1016/S0361-9230(02)00750-5)

Pavlides C, Watanabe Y, Magarinos AM \& McEwen BS 1995 Opposing role of adrenal steroid type I and type II receptors in hippocampal long-term potentiation. Neuroscience 68 387-394. (doi:10.1016/03064522(95)00151-8)

Pawlak R, Magarinos AM, Melchor J, McEwen B \& Strickland S 2003 Tissue plasminogen activator in the amygdala is critical for stress-induced anxietylike behavior. Nature Neuroscience 6 168-174. (doi:10.1038/nn998)

Pawlak R, Rao BSS, Melchor JP, Chattarji S, McEwen B \& Strickland S 2005 Tissue plasminogen activator and plasminogen mediate stressinduced decline of neuronal and cognitive functions in the mouse hippocampus. PNAS 102 18201-18206. (doi:10.1073/pnas. 0509232102)

Pereira AC, Lambert HK, Grossman YS, Dumitriu D, Waldman R, Jannetty SK, Calakos K, Janssen WG, McEwen BS \& Morrison JH 2014 Glutamatergic regulation prevents hippocampal-dependent agerelated cognitive decline through dendritic spine clustering. PNAS 111 18733-18738. (doi:10.1073/pnas.1421285111)

Pham K, Nacher J, Hof PR \& McEwen BS 2003 Repeated, but not acute, restraint stress suppresses proliferation of neural precursor cells and increases PSA-NCAM expression in the adult rat dentate gyrus. Journal of Neuroscience 17 879-886.

Popoli M, Yan Z, McEwen BS \& Sanacora G 2012 The stressed synapse: the impact of stress and glucocorticoids on glutamate transmission. Nature Reviews. Neuroscience 13 22-37.

van Praag H, Kempermann G \& Gage FH 1999 Running increases cell proliferation and neurogenesis in the adult mouse dentate gyrus. Nature Neuroscience 2 266-270. (doi:10.1038/6368)

Radley JJ, Sisti HM, Hao J, Rocher AB, McCall T, Hof PR, McEwen BS \& Morrison JH 2004 Chronic behavioral stress induces apical dendritic reorganization in pyramidal neurons of the medial prefrontal cortex. Neuroscience 125 1-6. (doi:10.1016/j.neuroscience.2004.01.006)

Radley JJ, Rocher AB, Janssen WGM, Hof PR, McEwen BS \& Morrison JH 2005 Reversibility of apical dendritic retraction in the rat medial prefrontal cortex following repeated stress. Experimental Neurology 196 199-203. (doi:10.1016/j.expneurol.2005.07.008)

Rao RP, Anilkumar S, McEwen BS \& Chattarji S 2012 Glucocorticoids protect against the delayed behavioral and cellular effects of acute stress on the amygdala. Biological Psychiatry 72 466-475. (doi:10.1016/j. biopsych.2012.04.008)

Ratman D, Vanden Berghe W, Dejager L, Libert C, Tavernier J, Beck IM \& De Bosscher K 2013 How glucocorticoid receptors modulate the activity of other transcription factors: a scope beyond tethering. Molecular and Cellular Endocrinology 380 41-54. (doi:10.1016/j.mce.2012.12.014)

Rettberg JR, Yao J \& Brinton RD 2014 Estrogen: a master regulator of bioenergetic systems in the brain and body. Frontiers in Neuroendocrinology 35 8-30. (doi:10.1016/j.yfrne.2013.08.001)

Reul JM \& DeKloet ER 1985 Two receptor systems for corticosterone in rat brain: microdistribution and differential occupation. Endocrinology 117 2505-2511. (doi:10.1210/endo-117-6-2505)

Romeo RD, Staub D, Jasnow AM, Karatsoreos IN, Thornton JE \& McEwen BS 2005 Dihydrotestosterone increases hippocampal $N$-methyl-D-aspartate binding but does not affect choline acetyltransferase cell number in the forebrain or choline transporter levels in the CA1 region of adult male rats. Endocrinology 146 2091-2097. (doi:10.1210/en.2004-0886)

Rudick CN, Gibbs RB \& Woolley CS 2003 A role for the basal forebrain cholinergic system in estrogen-induced disinhibition of hippocampal pyramidal cells. Journal of Neuroscience 23 4479-4490.

Russo SJ \& Charney DS 2013 Next generation antidepressants. PNAS 110 4441-4442. (doi:10.1073/pnas.1301593110)

Sandstrom NJ \& Williams CL 2001 Memory retention is modulated by acute estradiol and progesterone replacement. Behavioral Neuroscience 115 384-393. (doi:10.1037/0735-7044.115.2.384)

Sandstrom NJ \& Williams CL 2004 Spatial memory retention is enhanced by acute and continuous estradiol replacement. Hormones and Behavior 45 128-135. (doi:10.1016/j.yhbeh.2003.09.010)

Sapolsky R 1990 Glucocorticoids, hippocampal damage and the glutamatergic synapse. Progress in Brain Research 86 13-23.

Schally AV, Arimura A \& Kastin AJ 1973 Hypothalamic regulatory hormones. Science 179 341-350. (doi:10.1126/science.179.4071.341)

Schelling G, Roozendaal B \& De Quervain DJ-F 2004 Can posttraumatic stress disorder be prevented with glucocorticoids? Annals of the New York Academy of Sciences 1032 158-166. (doi:10.1196/annals.1314.013)

Seeman T, Epel E, Gruenewald T, Karlamangla A \& McEwen BS 2010 Socioeconomic differentials in peripheral biology: cumulative allostatic load. Annals of the New York Academy of Sciences 1186 223-239. (doi:10.1111/ j.1749-6632.2009.05341.x)

Shansky RM, Hamo C, Hof PR, McEwen BS \& Morrison JH 2009 Stressinduced dendritic remodeling in the prefrontal cortex is circuit specific. Cerebral Cortex 19 2479-2484. (doi:10.1093/cercor/bhp003)

Shansky RM, Hamo C, Hof PR, Lou W, McEwen BS \& Morrison JH 2010 Estrogen promotes stress sensitivity in a prefrontal cortex-amygdala pathway. Cerebral Cortex 20 2560-2567. (doi:10.1093/cercor/bhq003)

Sheline YI 2003 Neuroimaging studies of mood disorder effects on the brain. Biological Psychiatry 54 338-352. (doi:10.1016/S00063223(03)00347-0)

Shonkoff JP, Boyce WT \& McEwen BS 2009 Neuroscience, molecular biology, and the childhood roots of health disparities. Journal of the American Medical Association 301 2252-2259. (doi:10.1001/jama.2009.754)

Skrzypiec AE, Shah RS, Schiavon E, Baker E, Skene N, Pawlak R \& Mucha M 2013 Stress-induced lipocalin-2 controls dendritic spine formation and neuronal activity in the amygdala. PLoS ONE 8 e61046. (doi:10.1371/ journal.pone.0061046)

Sloan RP, Shapiro PA, Bagiella E, Myers MM \& Gorman JM 1999 Cardiac autonomic control buffers blood pressure variability responses to challenge: a psychophysiologic model of coronary artery disease. Psychosomatic Medicine 61 58-68. (doi:10.1097/00006842-19990100000010)

Smythe JW, Murphy D, Timothy C \& Costall B 1997 Hippocampal mineralocorticoid, but not glucocorticoid, receptors modulate anxietylike behavior in rats. Pharmacology, Biochemistry, and Behavior 56 507-513. (doi:10.1016/S0091-3057(96)00244-4)

Starkman MN, Gebarski SS, Berent S \& Schteingart DE 1992 Hippocampal formation volume, memory dysfunction, and cortisol levels in partiens

Published by Bioscientifica Ltd 
with Cushing's syndrome. Biological Psychiatry 32 756-765. (doi:10.1016/0006-3223(92)90079-F)

Stavreva DA, Wiench M, John S, Conway-Campbell BL, McKenna MA, Pooley JR, Johnson TA, Voss TC, Lightman SL \& Hager GL 2009 Ultradian hormone stimulation induces glucocorticoid receptormediated pulses of gene transcription. Nature Cell Biology $\mathbf{1 1}$ 1093-1102. (doi:10.1038/ncb1922)

Sterling P \& Eyer J 1988 Allostasis: a new paradigm to explain arousal pathology. In Handbook of Life Stress, Cognition and Health, pp. 629—649. Eds S Fisher \& J Reason. New York, NY: John Wiley \& Sons.

Towart LA, Alves SE, Znamensky V, Hayashi S, McEwen BS \& Milner TA 2003 Subcellular relationships between cholinergic terminals and estrogen receptor- $\alpha$ in the dorsal hippocampus. Journal of Comparative Neurology 463 390-401. (doi:10.1002/cne.10753)

Tracey KJ 2002 The inflammatory reflex. Nature $\mathbf{4 2 0} 853-859$ (doi:10.1038/nature01321)

Vale W, Spiess J, Rivier C \& Rivier J 1981 Characterization of a 41-residue ovine hypothalamic peptide that stimulates secretion of corticotropin and $\beta$-endorphin. Science 213 1394-1397. (doi:10.1126/science. 6267699)

Vyas A, Mitra R, Rao BSS \& Chattarji S 2002 Chronic stress induces contrasting patterns of dendritic remodeling in hippocampal and amygdaloid neurons. Journal of Neuroscience 22 6810-6818.
Waddington CH 1942 The epigenotype. Endeavour 1 18-20.

Weiland NG 1992 Estradiol selectively regulates agonist binding sites on the $N$-methyl-D-aspartate receptor complex in the CA1 region of the hippocampus. Endocrinology 131 662-668.

Weinstock M 2005 The potential influence of maternal stress hormones on development and mental health of the offspring. Brain, Behavior, and Immunity 19 296-308. (doi:10.1016/j.bbi.2004.09.006)

Woolley CS 1999 Effects of estrogen in the CNS. Current Opinion in Neurobiology 9 349-354. (doi:10.1016/S0959-4388(99)80051-8)

Yamamoto K 1985 Steroid receptor regulated transcription of specific genes and gene networks. Annual Review of Genetics 19 209-252. (doi:10.1146/ annurev.ge.19.120185.001233)

Yau PL, Castro MG, Tagani A, Tsui WH \& Convit A 2012 Obesity and metabolic syndrome and functional and structural brain impairments in adolescence. Pediatrics 130 e856-e864. (doi:10.1542/ peds.2012-0324)

Young EA, Lopez JF, Murphy-Weinberg V, Watson SJ \& Akil H 2003 Mineralocorticoid receptor function in major depression. Archives of General Psychiatry 60 24-28. (doi:10.1001/archpsyc.60.1.24)

Zohar J, Yahalom H, Kozlovsky N, Cwikel-Hamzany S, Matar MA, Kaplan Z, Yehuda R \& Cohen H 2011 High dose hydrocortisone immediately after trauma may alter the trajectory of PTSD: interplay between clinical and animal studies. European Journal of Oral Sciences 21 796-809.

Received in final form 17 March 2015

Accepted 1 May 2015

Accepted Preprint published online 1 May 2015
C 2015 Society for Endocrinology Printed in Great Britain
Published by Bioscientifica Ltd 